Article

\title{
Assessing the Optimum Level of Supplementation with Camelina Seeds in Ewes' Diets to Improve Milk Quality
}

\author{
Christos Christodoulou ${ }^{1}{ }^{\circledR}$, Alexandros Mavrommatis ${ }^{1} \mathbb{1}$, Christina Mitsiopoulou ${ }^{1}$, George Symeon ${ }^{2}$, \\ Vasilis Dotas $\left.{ }^{3} \mathbb{(}\right)$, Kyriaki Sotirakoglou ${ }^{4}\left(\mathbb{D}\right.$, Basiliki Kotsampasi ${ }^{2}$ and Eleni Tsiplakou ${ }^{1, * \mathbb{C}}$
}

1 Laboratory of Nutritional Physiology and Feeding, Department of Animal Science, School of Animal Biosciences, Agricultural University of Athens, Iera Odos 75, 11855 Athens, Greece; c.christodoulou@aua.gr (C.C.); mavrommatis@aua.gr (A.M.); chr_mitsiopoulou@aua.gr (C.M.)

2 Research Institute of Animal Science, Hellenic Agricultural Organization-Demeter, 58100 Giannitsa, Greece; symeon@rias.gr (G.S.); vkotsampasi.arig@nagref.gr (B.K.)

3 Department of Animal Production, School of Agriculture, Aristotle University of Thessaloniki, 54124 Thessaloniki, Greece; vdotas@agro.auth.gr

4 Laboratory of Mathematics and Statistics, Department of Natural Resources and Agricultural Engineering, School of Environment and Agricultural Engineering, Agricultural University of Athens, Iera Odos 75, 11855 Athens, Greece; sotirakoglou@aua.gr

* Correspondence: eltsiplakou@aua.gr; Tel.: +30-21-0529-4435; Fax: +30-21-0529-4413

check for updates

Citation: Christodoulou, C.; Mavrommatis, A.; Mitsiopoulou, C.; Symeon, G.; Dotas, V.; Sotirakoglou, K.; Kotsampasi, B.; Tsiplakou, E. Assessing the Optimum Level of Supplementation with Camelina Seeds in Ewes' Diets to Improve Milk Quality. Foods 2021, 10, 2076. https://doi.org/ 10.3390 /foods 10092076

Academic Editor: Ana

M Vivar-Quintana

Received: 4 August 2021

Accepted: 30 August 2021

Published: 2 September 2021

Publisher's Note: MDPI stays neutral with regard to jurisdictional claims in published maps and institutional affiliations.

Copyright: (c) 2021 by the authors Licensee MDPI, Basel, Switzerland. This article is an open access article distributed under the terms and conditions of the Creative Commons Attribution (CC BY) license (https:// creativecommons.org/licenses/by/ $4.0 /)$
Abstract: Camelina sativa seeds are rich in bioactive compounds such as polyunsaturated fatty acids (PUFA) and antioxidants, thus, their supplementation in ewes' diets, may be an effective way to develop high nutritional dairy products. Therefore, the present study investigates the effect of the dietary inclusion of Camelina sativa seeds in ewes' oxidative status and milk quality. Fortyeight dairy Chios ewes were divided into four homogenous groups and were fed individually. The concentrate of the control group (CON) had no inclusion of Camelina seeds, while the treatment groups (CSS6, CSS11, CSS16) were supplemented with 6\%, 11\%, and 16\%, respectively. Including Camelina seeds in $6 \%$ and $11 \%$, had no impact on milk performance, while in the CSS16, milk fat was significantly decreased compared to the CON. Supplementing Camelina seeds improved milk quality from a human health perspective by modifying the content of saturated fatty acid, the proportions of $\alpha$-linolenic $\left(\mathrm{C}_{18: 3} \mathrm{n}-3\right)$, and $\mathrm{C}_{18: 2 \text { cis-9, trans-11 }}$ (CLA), and the $\omega 6 / \omega 3$ ratio. Furthermore, the activity of catalase (CAT) was significantly increased in the CSS11 and CSS16, and superoxide dismutase (SOD) activity also significantly upsurged in the CSS16. Still, the levels of malondialdehyde (MDA) were significantly increased in the CSS11 compared to the CON and CSS6, and in the CSS16 compared to the CSS6. In CSS16, protein carbonyls were significantly increased. Finally, in the CSS-fed ewes, milk oxidative stability was fortified, as suggested by the modifications in the activities of SOD, CAT, and glutathione peroxidase (GSH-Px), in the antioxidant capacity, and the oxidative stress biomarkers. Consequently, the incorporation of $6 \%$ Camelina seeds in the concentrates of ewes improves milk's fatty acid profile and oxidative status. However, more research is required regarding the possible negative effects of the constant consumption of Camelina seeds by ewes.

Keywords: Camelina sativa; fatty acid profile; dairy; sheep; CLA; malondialdehyde; antioxidants; total antioxidant capacity

\section{Introduction}

In humans, the high intake of saturated fatty acids (SFA) has been associated with prospective risk of cardiovascular diseases, obesity, and metabolic syndrome [1], while that of monounsaturated (MUFA) and polyunsaturated fatty acids (PUFA) is associated with an improvement of dietary lipoprotein profiles, resulting in a plethora of benefits for human health [2]. Thus, manipulations in ruminants' diets are studied aiming to alter milk fatty acids (FA) and manufacture functional dairy products with high economic and health potential. 
The inclusion of oilseeds rich in $\omega 3$ PUFA in ruminants' diets appears to be a welldocumented nutritional strategy to enrich ruminants' milk with such bioactive molecules. Camelina is a low-input oilseed crop with superior nutrient efficiency that can grow with limited nitrogen fertilization [3]. Camelina seeds contain $40-44 \%$ crude protein and $39-47 \%$ fat depicting an interesting protein and energy source for high-yielding dairy animals. These aspects increase Camelina seeds and their by-products' potential to partially substitute conventional feeds such as soya, thus preserving the biodiversity with simultaneous beneficial environmental outputs that are linked with vast soya cultivation on a global scale (e.g., deforestation, alternative use of land with fewer resources) [4]. However, due to antinutritional compounds that are presented in Camelina such as glucosinolates, tannins and erucic acid [5], the effect of constant consumption and its possible impact on the performance of animals should be also considered.

So far, the dietary supplementation with $\omega 3$ PUFA-rich Camelina Sativa seeds (CSS) resulted in an improvement on ewes' milk FA profile from a human health point of view [6-8]. However, in these studies, the ewes were fed ad libitum on a group basis with pasture [6,8] or silage-based diets [7] which were also rich in $\omega 3$ PUFA ( $\alpha$-linolenic acid; $C_{18: 3 n-3}$ (ALA)). Furthermore, the narrow dietary inclusion levels of CSS (70 to $100 \mathrm{~g} /$ ewe/day) that were used in the aforementioned studies in combination with the type of forages (fresh; pastures, or silages) does not allow us to draw robust conclusions about the optimum supplementation level of ewes' diets with CSS per se. Considering the above, more research is required to define the optimum supplementation level with CSS in ewes' diets towards the enrichment of milk with PUFA.

Even though the proportion of milk $\omega 3$ may be positively correlated with their dietary intake; extent levels of PUFA could adversely affect rumen fermentation, volatile fatty acids (VFA) production, and consequently animals' performance. More specifically, the partial inhibition of principal rumen function, such as the biohydrogenation results in high accu-

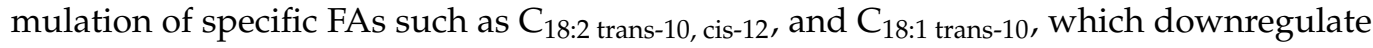
the lipogenesis in the mammary gland [9]. Thus, the dietary inclusion level of oilseeds rich in PUFA in ruminants should be holistically investigated, aiming to exclude the induction of adverse effects on animals' performance, since plenty of cofactors such as animal species (goat, ewes, cows), lactation stage, oilseed, and forage type may synergistically act as well.

Furthermore, supplementing high levels of oilseeds rich in PUFA may be a precursor of oxidative stress due to the high propensity of PUFA to oxidation. PUFA oxidation could trigger a cascade of prooxidant incidence disturbing the organism's antioxidative balance and compromising milk oxidative status through the formation of detrimental aldehydes such as the malondialdehyde (MDA) [10]. Although high dietary PUFA levels could induce oxidative imbalances, prudent doses can activate antioxidant mechanisms in several cells [11]. In addition, Camelina oil is a pivotal source of tocopherols [12], a potent inhibitor of lipid peroxidation [13]. Considering the above, it is plausible to assume that the interaction of Camelina's PUFA and antioxidants' compounds are noteworthy for study under a more holistic lens.

The objective of this work was to investigate the effects of dietary supplementation with CSS at three different levels $(6 \%, 11 \%$, and $16 \%)$ in milk yield and its chemical composition, and in FAs profile in ewes' milk and blood plasma, having alfalfa hay and wheat straw as forages. At the same time, to evaluate the activity of key targeted antioxidant enzymes, such as glutathione peroxidase (GSH-Px), catalase (CAT), superoxide dismutase (SOD), glutathione reductase (GR), and glutathione transferase (GST) in ewes blood plasma, also GSH-Px, CAT, and SOD in ewes' milk, the total antioxidant capacity [2,2'-Azino-bis (3ethylbenzthiazoline-6-sulfonic acid) (ABTS) and the ferric reducing ability of both plasma and milk (FRAP)] and oxidative stress indicators such as malondialdehyde (MDA) and protein carbonyls (PCs) in both blood plasma and ewes' milk. 


\section{Materials and Methods}

\subsection{Experimental Design and Diets}

Forty-eight dairy Chios ewes, 2-4 years old and of comparable body weight (BW) $(55.0 \pm 6.5 \mathrm{~kg})$ were kept at the Research Institute of Animal Science, Hellenic Agricultural Organization-Demeter (Giannitsa, Greece; $40^{\circ} 44^{\prime} \mathrm{N}, 22^{\circ} 27^{\prime} \mathrm{E}$ ). Housing and care of the animals conformed to Ethical Committee guidelines of the Faculty of Animal Science (EU 63/2010; Council of the European Union 2010). Ewes were divided into four equal groups $(n=12)$ regarding $\mathrm{BW}$, fat corrected $(6 \%)$ milk yield $(\mathrm{FCM})(1.85 \pm 0.3 \mathrm{~kg} / \mathrm{d})$, days in milk $(67 \pm 8)$, and age ( $2-4$ years old). Throughout the experimental period, ewes were kept in groups at a common stall and were fed individually.

The rations consisted of alfalfa hay, wheat straw, and concentrate and were formulated to be isonitrogenous with comparable caloric content amongst the groups. The daily feed intakes of the concentrate, alfalfa hay, and wheat straw were $1.5,1.5$, and $0.2 \mathrm{~kg} /$ ewe/day, respectively, and were offered at the same level, at each group, twice per day, after milking 07:00 and 17:00 (Table 1). The concentrate of the control group (CON) had no Camelina seeds, while in the three following groups (CSS6, CSS11, and CSS16), Camelina seeds were included at three different levels by partial substitution of soybean meal and maize grain $(6,11$, and $16 \%$, respectively) (Table 1$)$. The concentrate consisted of maize grain, barley, wheat, sunflower meal, soybean meal, calcium carbonate, calcium phosphate, mineral and vitamin premix, and salt (Table 1). Before the official beginning of the experiment, there was a one-week adaptation period, mostly for the ewes to acclimatize to the new environment of individual feeding. Following the adaptation period, ewes were offered concentrate with the inclusion of three different levels of Camelina seeds. All animals had free access to fresh water. The main experimental period lasted 60 days.

Table 1. Concentrates composition ( $\mathrm{g} / \mathrm{kg}$ ), diet intake $(\mathrm{g})$, daily nutrients intake (g/ewe), and feeds chemical composition and fatty acid profile (\%).

\begin{tabular}{|c|c|c|c|c|}
\hline \multirow[t]{2}{*}{ Ingredients (\%) } & \multicolumn{4}{|c|}{ Concentrates } \\
\hline & $\mathrm{CON}$ & CSS6 & CSS11 & CSS16 \\
\hline Camelina seeds & 0.0 & 6.0 & 11.0 & 16.0 \\
\hline Maize grain & 34.4 & 29.9 & 26.9 & 23.9 \\
\hline Barley & 20.0 & 20.0 & 20.0 & 20.0 \\
\hline Wheat middlings & 10.0 & 10.0 & 10.0 & 10.0 \\
\hline Sunflower meal & 16.0 & 18.0 & 18.0 & 18.0 \\
\hline Soybean meal & 15.5 & 12.0 & 10.0 & 8.0 \\
\hline Premix mineral and vitamins & 4.1 & 4.1 & 4.1 & 4.1 \\
\hline \multirow[t]{2}{*}{ Daily feed intake (g/ewe/d) } & \multicolumn{4}{|c|}{ Treatments } \\
\hline & $\mathrm{CON}$ & CSS6 & CSS11 & CSS16 \\
\hline Wheat Straw & 200 & 200 & 200 & 200 \\
\hline Alfalfa Hay & 1500 & 1500 & 1500 & 1500 \\
\hline Concentrate & 1500 & 1500 & 1500 & 1500 \\
\hline \multirow[t]{2}{*}{ Nutrients intake (g/day/ewe) } & \multicolumn{4}{|c|}{ Treatments } \\
\hline & $\mathrm{CON}$ & CSS6 & CSS11 & CSS16 \\
\hline Dry Matter & 2880 & 2874 & 2882 & 2888 \\
\hline Crude Protein & 601 & 600 & 602 & 620 \\
\hline Ether Extract & 40 & 80 & 107 & 133 \\
\hline Neutral Detergent Fiber & 1284 & 1285 & 1287 & 1301 \\
\hline Acid Detergent Fiber & 665 & 711 & 712 & 719 \\
\hline
\end{tabular}


Table 1. Cont.

\begin{tabular}{|c|c|c|c|c|c|c|}
\hline & \multicolumn{6}{|c|}{ Chemical composition (\% DM) } \\
\hline & $\begin{array}{c}\text { Alfalfa } \\
\text { hay }\end{array}$ & Wheat straw & $\begin{array}{l}\text { CON } \\
\text { con. }\end{array}$ & $\begin{array}{l}\text { CSS6 } \\
\text { con. }\end{array}$ & CSS11 con. & CSS16 con. \\
\hline Dry Matter & 89.40 & 92.80 & 90.24 & 89.85 & 90.38 & 90.74 \\
\hline Crude Protein & 20.00 & 0.48 & 20.03 & 19.96 & 20.09 & 21.30 \\
\hline Ether Extract & 0.28 & 0.16 & 2.36 & 5.00 & 6.80 & 8.55 \\
\hline Neutral Detergent Fiber & 60.60 & 72.80 & 15.29 & 15.34 & 15.52 & 16.42 \\
\hline \multirow[t]{2}{*}{ Acid Detergent Fiber } & 32.50 & 49.30 & 5.29 & 8.35 & 8.36 & 8.85 \\
\hline & \multicolumn{6}{|c|}{ Fatty acids composition ( $\%)$} \\
\hline \multirow[t]{2}{*}{ Fatty acid } & \multicolumn{3}{|c|}{ Concentrates } & \multicolumn{3}{|c|}{ Forages } \\
\hline & $\begin{array}{l}\text { CON } \\
\text { con. }\end{array}$ & CSS6 con. & $\begin{array}{l}\text { CSS11 } \\
\text { con. }\end{array}$ & $\begin{array}{l}\text { CSS16 } \\
\text { con. }\end{array}$ & Alfalfa Hay & Wheat Straw \\
\hline $\mathrm{C}_{14: 0}$ & 0.18 & 0.16 & 0.15 & 0.10 & 2.35 & 6.16 \\
\hline $\mathrm{C}_{15: 0}$ & 0.00 & 0.04 & 0.04 & 0.03 & 0.68 & 0.83 \\
\hline $\mathrm{C}_{16: 0}$ & 15.71 & 10.18 & 8.63 & 7.68 & 43.53 & 33.38 \\
\hline$C_{16: 1 n-7}$ & 0.22 & 0.14 & 0.12 & 0.11 & 2.99 & 0.00 \\
\hline $\mathrm{C}_{17: 0}$ & 0.21 & 0.10 & 0.09 & 0.08 & 0.83 & 0.00 \\
\hline $\mathrm{C}_{17: 1 \mathrm{n}-7}$ & 0.41 & 0.10 & 0.08 & 0.04 & 0.00 & 0.00 \\
\hline $\mathrm{C}_{18: 0}$ & 2.94 & 2.46 & 2.28 & 2.17 & 6.79 & 4.28 \\
\hline $\mathrm{C}_{18: 1 \text { trans }}$ & 0.20 & 0.10 & 0.11 & 0.05 & 0.00 & 0.00 \\
\hline $\mathrm{C}_{18: 1 \text { cis-9 }}$ & 20.65 & 17.89 & 17.84 & 17.35 & 3.01 & 9.00 \\
\hline$C_{18: 2 n-6 \text { cis }}$ & 54.14 & 37.75 & 30.36 & 28.77 & 16.34 & 26.74 \\
\hline$C_{18: 3 n-6}$ & 0.00 & 0.12 & 0.13 & 0.14 & 0.00 & 0.00 \\
\hline $\mathrm{C}_{20: 0}$ & 0.23 & 0.40 & 0.47 & 0.50 & 0.70 & 1.12 \\
\hline$C_{18: 3 n-3}$ & 3.41 & 18.11 & 21.76 & 23.44 & 18.59 & 11.22 \\
\hline $\mathrm{C}_{20: 1 \mathrm{n}-9}$ & 0.59 & 8.95 & 11.19 & 12.19 & 0.00 & 0.00 \\
\hline$C_{20: 2 n-6}$ & 0.46 & 1.13 & 1.35 & 1.40 & 0.00 & 0.00 \\
\hline $\mathrm{C}_{22: 0}$ & 0.00 & 0.08 & 0.10 & 0.07 & 1.48 & 3.99 \\
\hline$C_{20: 3 n-3}$ & 0.40 & 0.32 & 0.33 & 0.32 & 0.00 & 0.00 \\
\hline $\mathrm{C}_{22: 1 \mathrm{n}-9}$ & 0.00 & 0.65 & 0.82 & 0.90 & 0.00 & 0.00 \\
\hline $\mathrm{C}_{24: 0}$ & 0.27 & 0.18 & 0.19 & 0.19 & 2.71 & 1.94 \\
\hline$C_{24: 1 \mathrm{n}-9}$ & 0.00 & 0.32 & 0.40 & 0.46 & 0.00 & 0.00 \\
\hline
\end{tabular}

CON: 0\% Camelina seeds; CSS6: 6\% Camelina seeds; CSS11: 11\% Camelina seeds; CSS16: 16\% Camelina seeds.

\subsection{Samples Collection}

Ewes were milked twice per day at 07:00 and 17:00 by a milking machine. Individual milk samples $(n=240)$ were collected at $0,15,30,45$, and 60 experimental days for milk chemical composition analysis and at $15,30,45$, and 60 experimental days $(n=192)$ for milk FA profile determination and antioxidative status (five aliquots of $15 \mathrm{~mL}$ each). The stored milk aliquots were obtained after mixing a yield from the evening and the following morning milk on an identical percent volume (5\%). Individual blood samples $(n=192)$ were also collected at $15,30,45$, and 60 experimental days from the jugular vein of each ewe after the milking, prior to access on feeds. Approximately $10 \mathrm{~mL}$ of whole blood were immediately transferred to heparin-containing tubes (170 units heparin; BD Vacutainer, Plymouth, UK). Then, the blood samples were centrifuged (SL16R, Thermo Fisher Scientific, Waltham, MA, USA) at $2500 \mathrm{rpm}$ for $15 \mathrm{~min}$ at $4{ }^{\circ} \mathrm{C}$ to separate plasma from the cells. Both the milk and blood samples were stored at $-80^{\circ} \mathrm{C}$, before analysis. Furthermore, feed samples from alfalfa hay, wheat straw, and concentrate were collected at the beginning of the experiment, and every time a new concentrate was formulated. Samples of Camelina seeds were also collected for chemical analysis every time a new concentrate was formulated. 


\subsection{Sample Analysis}

\subsubsection{Feed Samples}

Individual feed samples from alfalfa hay, wheat straw, Camelina seeds, and concentrates were collected and analyzed for organic matter (OM; Official Method 7.009), dry matter (DM; Official Method 7.007), and crude protein (CP; Official Method 7.016) according to AOAC [14]. Briefly, $0.5 \mathrm{~g}$ of $1 \mathrm{~mm}$ ground feedstuff was duplicate analyzed using a FOSS Kjeltec ${ }^{\mathrm{TM}} 8400$ Analyzer Unit and a FOSS Digestion System DT220 (FOSS, Hillerød, Denmark) to estimate the nitrogen content, and then crude protein content was obtained by multiplying $\mathrm{N} \times 6.25$. Furthermore, ether extract was assayed based on Soxhlet [15] using $70 \mathrm{~mL}$ of petroleum ether (Sigma-Aldrich, St. Louis, MO, USA) per $1 \mathrm{~g}$ of $1 \mathrm{~mm}$ ground feedstuff for $50 \mathrm{~min}$. Feed samples were also analyzed for neutral detergent fibre (NDF), assayed with a heat-stable amylase (Sigma-Aldrich, St. Louis, MO, USA) and acid detergent fibre (ADF), expressed exclusive of residual ash according to Van Soest et al. [16] using an ANKOM 2000 fiber analyzer and F57 filter bags (ANKOM Technology, Macedon, NY, USA) (Table 1). Feed samples were also analyzed for the determination of FA profile according to the method of $\mathrm{O}^{\prime}$ Fallon et al. [17] (Table 1).

\subsubsection{Milk Chemical Composition}

Individual milk samples were analyzed for fat, protein, lactose, and solids-not-fat (SNF) using infrared spectroscopy (Milkoscan 6000; FOSS, Hillerød, Denmark), and for somatic cell counts (SCC) using Fossomatic 400 cell counter (FOSS, Hillerød, Denmark). Fat corrected- $\left(\mathrm{FCM}_{6 \%}\right)$ and energy corrected- $(\mathrm{ECM})$ milk yield was calculated using the following formulas:

Fat corrected milk (FCM) in 6\% based on Equation (1).

$$
\mathrm{FCM}_{6 \%}=(0.28+0.12 \times \mathrm{F}) \times \mathrm{M},
$$

where $\mathrm{F}=$ fat content $(\%)$ and $\mathrm{M}=$ milk yield in $\mathrm{kg}$.

Energy corrected milk (ECM) yield based on Equation (2).

$$
\mathrm{ECM}=\text { milk yield } \times(0.071 \times \text { fat }(\%)+0.043 \times \text { protein }(\%)+0.2224) .
$$

\subsubsection{Fatty Acid Determination}

The plasma fatty acid analysis was carried out according to the method of Bondia-Pons et al. [18]. The extraction and methylation of milk fatty acids were performed based on a two-step procedure as previously described by Tsiplakou et al. [19]. The FA profile was analyzed as described by Mavrommatis and Tsiplakou [20]. More specifically, an Agilent $6890 \mathrm{~N}$ gas chromatograph equipped with an HP-88 capillary column $(60 \mathrm{~m} \times 0.25 \mathrm{~mm}$ i.d. with $0.20 \mu \mathrm{m}$ film thickness, Agilent) and a flame ionization detector, was used. A flame ionization detector (FID) temperature was set at $260^{\circ} \mathrm{C}$ and the chromatographic analysis involved a temperature programmed run starting at $120^{\circ} \mathrm{C}$ and held for $1 \mathrm{~min}$. It was followed by two step-up ramps, one of $1.25^{\circ} \mathrm{C} / \mathrm{min}$ to $230^{\circ} \mathrm{C}$, and another of $10^{\circ} \mathrm{C} / \mathrm{min}$ to $240^{\circ} \mathrm{C}$ and held for $3 \mathrm{~min}$. Hydrogen was used as the carrier gas with a linear velocity set at $30 \mathrm{~cm} / \mathrm{s}$ and helium as make up gas. Each peak was identified and quantified using a 37 component FAME mix standard (Supelco, Sigma Adrich Co., St. Louis, MO, USA). Additionally, extra standards were used for the $C_{18: 2}$ cis-9, trans-11, $C_{18: 2}$ trans-10, cis-12, and $C_{18: 1 \text { trans-11 }}$ FA (Sigma Adrich Co., St. Louis, MO, USA). A Tricosanoic methyl ester $\left(C_{23: 0}\right)$ was used as an internal standard for the chromatographic analysis (Fluka, Sigma Aldrich Co., St. Louis, MO, USA) for the milk samples and Tridecanoic $\left(\mathrm{C}_{13: 0}\right)$ for the blood plasma samples. The groups of FA were defined based on Tsiplakou et al. [21] as follow:

$$
\begin{aligned}
& \text { Short-Chain Saturated Fatty Acids (SCFA) }=C_{4: 0}+C_{6: 0}+C_{8: 0}+C_{10: 0}+C_{11: 0} \\
& \text { Medium-Chain Saturated Fatty Acids (MCFA) }=C_{12: 0}+C_{14: 0}+C_{15: 0}+C_{16: 0} \\
& \text { Long-Chain Saturated Fatty Acids (LCFA) }=C_{17: 0}+C_{18: 0}+C_{20: 0}+C_{22: 0}
\end{aligned}
$$




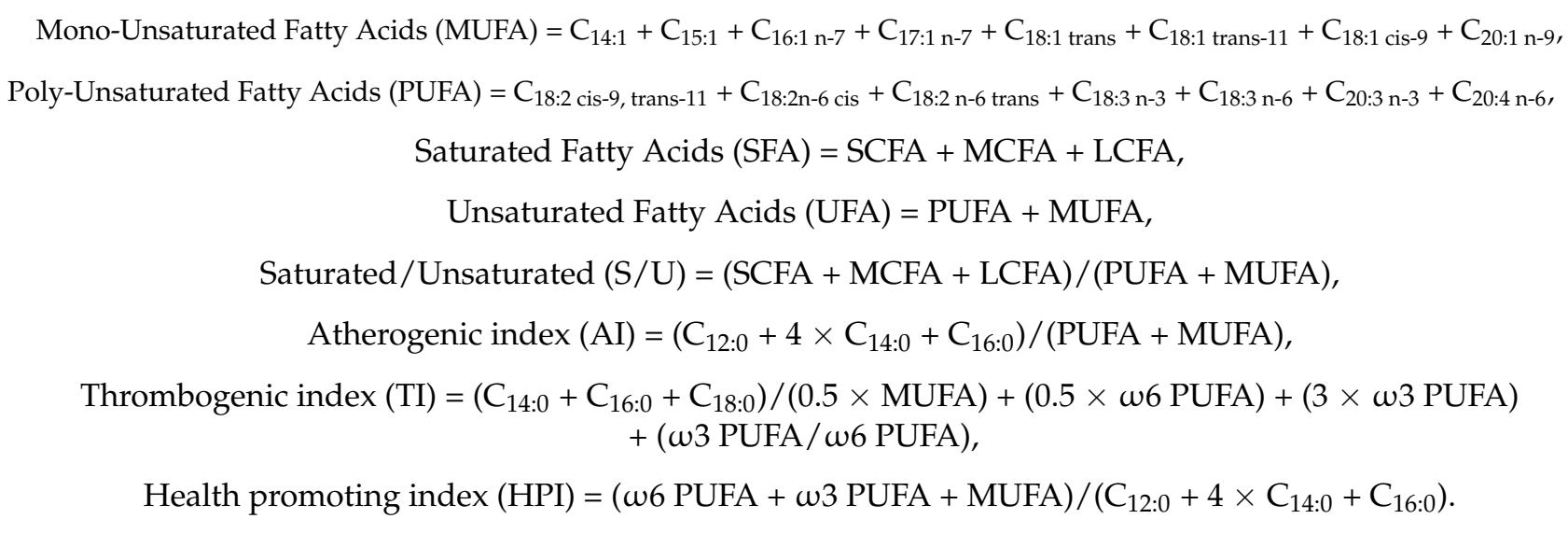

\subsubsection{Antioxidant Enzyme Activities and Oxidative Status Indicators}

The assays for antioxidant enzyme activities, oxidative stress indicators, and the total antioxidant capacity were performed using a UV/Vis spectrophotometer (GENESYS 180, Thermo Fisher Scientific, Waltham, MA, USA) as previously described [22]. The GSTs activities were estimated by monitoring the conjunction of GSH to 1-chloro-2,4-dinitrobenzene (CDNT) at $340 \mathrm{~nm}$. CAT activity was assessed using a commercial spectrophotometric kit (Catalase Assay Kit; CAT100, Sigma-Aldrich, St. Louis, MO, USA). GSH-Px activity was proportionally assayed by monitoring the decrease in the nicotinamide adenine dinucleotide phosphate (NADPH) absorbance at $340 \mathrm{~nm}$, in the presence of $\mathrm{H}_{2} \mathrm{O}_{2}$. GR activity was determined by measuring the reduction of oxidized glutathione (GSSG) to reduce glutathione in presence of NADPH at $340 \mathrm{~nm}$. SOD activity was recorded by monitoring the inhibition of cytochrome $\mathrm{c}$ oxidation at $550 \mathrm{~nm}$. MDA was measured according to Nielsen et al. [23] with some modifications described by Tsiplakou et al. [22]. The protein carbonyls (PC) were assayed according to the method of Patsoukis et al. [24]. The ABTS [2,2'-azino-bis(3-ethylbenz-thiazoline-6-sulfonic acid] and the ferric reducing ability of plasma (FRAP) were used to assess the total antioxidant capacity by the decolorization of ABTS + cation radical at $734 \mathrm{~nm}$ and by monitoring the reduction of $\mathrm{Fe}^{3+}$ into $\mathrm{Fe}^{2+}$ using 2,4,6-tripyridyl-s-triazine at $593 \mathrm{~nm}$ respectively. The full assays and sample quantities are available in the Supplementary Materials.

\subsection{Statistical Analysis}

The dataset was evaluated in SPSS.IBM software (v 24.0, IBM Corp., Armonk, NY, USA) and the results are depicted as mean \pm standard error of means (SEM). The effect of dietary treatment between four groups was assessed by performing a GLM for repeated measures analysis of variance. The dietary treatments (D) (D = CON, CSS6, CSS11, and CSS16) were defined as the fixed factor and the sampling time (S) $(0,15,30,45$, and 60 days for milk yield and chemical composition and 15, 30, 45, and 60 days for fatty acids and antioxidative status in blood plasma and milk) as the repeated measure, while their interactions $(\mathrm{D} \times \mathrm{S})$ were also assessed, according to the following model:

$$
Y_{i j k l}=\mu+D_{i}+S_{j}+A_{k}+(D \times S)_{i j}+e_{i j k l}
$$

where is $Y_{i j k l}$ the dependent variable, $\mu$ the overall mean, $D_{i}$ the effect of dietary treatment $\left(i=4 ;\right.$ CON, CSS6, CSS11, and CSS16), $S_{j}$ the effect of sampling time $(j=5 ; 0,15,30,45$, and 60 days for milk yield and chemical composition or $j=4 ; 15,30,45$, and 60 days for fatty acids and antioxidative status in blood plasma and milk), $A_{k}$ is the animal's random effect, $(D \times S)_{i j}$ the interaction between dietary treatments and sampling time, and $e_{i j k l}$ the residual errors. A total of 240 observations (12 ewes $\times 4$ dietary groups $\times$ 5 sampling times) emerged for milk yield and chemical composition while a total of 192 observations (12 ewes $\times 4$ dietary groups $\times 4$ sampling times) were obtained for fatty acids and antioxidative status in blood plasma and milk, respectively. Post-hoc analysis was 
applied with appropriate use of Tukey's multiple range test. For all tests, the significance level was set at $p=0.05$. Simplifying the visualization of these results, GraphPad Prism 6.0 (2012) depicted interleaved bars.

Discriminant analyses were also performed (variables were entered independent together; Figure 2A and using a stepwise method; Figure 2B) on milk fatty acids pooled data to establish those variables capable of distinguishing and classifying samples amongst the four dietary groups (CON, CSS6, CSS11, and CSS16). Wilk's lambda ( $\lambda$ ) criterion was used for assessing discriminant functions. Fifty-five variables for milk fatty acid profile were entered to create two models to distinguish the one hundred ninety-two samples of each case $(4$ groups $\times 12$ ewes/group $\times 4$ sampling time). Moreover, Pearson correlations were performed in the milk fatty acid profile featuring significant correlations between individual fatty acids.

\section{Results}

\subsection{Feeds Fatty Acid Profile}

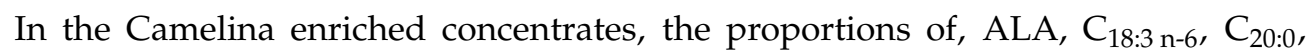

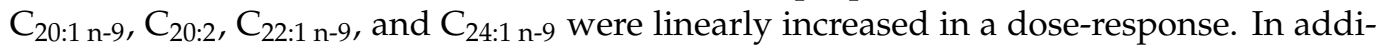

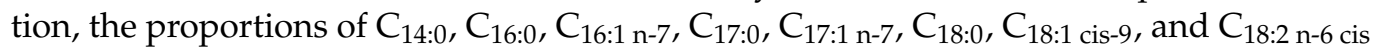
linearly decreased in a dose-dependent manner in the concentrates of the treated groups. Finally, the proportions of $\mathrm{C}_{15: 0}$ and $\mathrm{C}_{22: 0}$ were higher in the CSS concentrates, while the proportions of $C_{18: 1 \text { trans }}, C_{20: 3 n-3}$, and $C_{24: 0}$ were lower (Table 1 ).

\subsection{Milk Yield and Milk Chemical Composition}

At the beginning of the trial (0th experimental day), there were no significant differences in milk yield and milk chemical composition among the four experimental groups. During the experimental period, and compared to the CON, milk yield showed a tendency to increase in the treated with Camelina seeds ewes, but it was not statistically significant (Table 2). Regarding milk chemical composition, milk fat was significantly decreased in the CSS16 compared to the CON and CSS11 ( $p=0.046)$. Furthermore, total solids were found to be significantly elevated $(p=0.054)$ in the CSS11 compared to the CSS16. Fat yield, FCM, ECM, protein, protein yield, lactose, solids not fat (SNF), and somatic cell count (SCC) were not significantly affected (Table 2 ).

Table 2. Milk yield and chemical composition from ewes fed diets with different levels (CON, CSS6, CSS11, CSS16) with different levels of Camelina seeds $(6 \%, 11 \%$, and $16 \%$ of concentrate) throughout the experimental period $(0,15$ th, 30th, 45th, and 60th experimental days.

\begin{tabular}{|c|c|c|c|c|c|c|c|c|c|c|c|c|c|c|}
\hline & \multicolumn{4}{|c|}{ Dietary Treatments (D) } & \multicolumn{7}{|c|}{ Sampling Time (S) } & \multicolumn{3}{|c|}{ Effect $^{b}$} \\
\hline & Control & CSS6 & CSS11 & CSS16 & $\underset{\mathbf{a}}{\mathrm{SEM}}$ & 0 & 15 & 30 & 45 & 60 & $\underset{\mathbf{a}}{\text { SEM }}$ & D & S & $\mathbf{D} \times \mathbf{S}$ \\
\hline Milk yield (g/d) & 1705.0 & 1856.7 & 1873.7 & 1887.3 & 87.73 & $1973.1^{C}$ & $1869.8^{\mathrm{B}}$ & $1866.7^{\mathrm{BC}}$ & $1700.0^{\mathrm{AB}}$ & $1743.8^{\mathrm{BC}}$ & 53.05 & 0.433 & $<0.001$ & 0.050 \\
\hline Fat $(\%)$ & $5.89^{b}$ & $5.71^{a b}$ & $5.85^{b}$ & $5.35^{\mathrm{a}}$ & 0.145 & $5.560^{\mathrm{A}}$ & $6.021^{\text {B }}$ & $5.477^{\mathrm{A}}$ & $5.976^{\text {B }}$ & $5.461^{\mathrm{A}}$ & 0.103 & 0.046 & $<0.001$ & $<0.001$ \\
\hline Fat yield (g/d) & 99.76 & 105.74 & 107.1 & 99.75 & 2.663 & $107.77^{\mathrm{A}}$ & $112.12 \mathrm{~A}$ & $101.13^{\mathrm{B}}$ & $100.35^{\text {B }}$ & $94.01^{\mathrm{C}}$ & 2.888 & 0.511 & $<0.001$ & 0.131 \\
\hline $\operatorname{FCM}_{(6 \%)}(\mathrm{g} / \mathrm{d})^{\mathrm{c}}$ & 1678.1 & 1788.7 & 1809.2 & 1725.5 & 73.43 & $1845.7^{\mathrm{BC}}$ & $1869.0^{\mathrm{C}}$ & $1736.2 \mathrm{AB}$ & $1684.6^{\mathrm{A}}$ & $1616.4^{\mathrm{A}}$ & 46.87 & 0.577 & $<0.001$ & 0.252 \\
\hline $\operatorname{ECM}(\mathrm{g} / \mathrm{d})^{d}$ & 1470.84 & 1584.03 & 1633.53 & 1576.46 & 38.525 & $1648.12^{\mathrm{A}}$ & $1658.51^{\mathrm{A}}$ & $1562.62^{\mathrm{B}}$ & $1496.42^{C}$ & $1465.40^{\mathrm{C}}$ & 42.968 & 0.424 & $<0.001$ & 0.193 \\
\hline Protein (\%) & 5.218 & 5.285 & 5.435 & 5.236 & 0.072 & $5.291 \mathrm{AB}$ & $5.377^{\text {B }}$ & $5.233^{\mathrm{A}}$ & $5.267 \mathrm{AB}$ & 5.299 АВ & 0.044 & 0.145 & 0.010 & 0.008 \\
\hline Protein yield (g/d) & 89.15 & 97.76 & 101.26 & 98.60 & 2.487 & $103.93 \mathrm{~A}$ & $100.38 \mathrm{AB}$ & $97.56^{\mathrm{B}}$ & $89.41^{\mathrm{C}}$ & $92.17^{\mathrm{C}}$ & 2.796 & 0.267 & $<0.001$ & 0.067 \\
\hline Lactose $(\%)$ & 4.943 & 5.002 & 5.044 & 5.028 & 0.047 & $5.075^{\mathrm{C}}$ & $5.003 \mathrm{AB}$ & $4.971^{\mathrm{AB}}$ & $4.949^{\mathrm{A}}$ & 5.022 BC & 0.027 & 0.456 & $<0.001$ & 0.011 \\
\hline $\operatorname{SCC}(1000 / \mathrm{mL})^{\mathrm{e}}$ & 349.72 & 601.62 & 454.68 & 352.87 & 168.56 & $204.50^{\mathrm{a}}$ & $599.63^{B}$ & $496.40 \mathrm{AB}$ & $415.84 \mathrm{AB}$ & $482.25 \mathrm{AB}$ & 101.55 & 0.689 & 0.011 & 0.502 \\
\hline Total Solids (\%) & $16.73^{\mathrm{ab}}$ & $16.56^{\mathrm{ab}}$ & $16.90^{\mathrm{b}}$ & $16.18^{\mathrm{a}}$ & 0.185 & 16.49 & 16.97 & 16.25 & 16.76 & 16.48 & 0.120 & 0.054 & $<0.001$ & $<0.001$ \\
\hline Solis Not Fat (\%) & 10.84 & 10.86 & 11.05 & 10.83 & 0.078 & $10.93 b^{c}$ & $10.95^{\mathrm{C}}$ & $10.78^{\mathrm{A}}$ & $10.79 \mathrm{AB}$ & $11.02^{\mathrm{C}}$ & 0.052 & 0.165 & $<0.001$ & $<0.001$ \\
\hline
\end{tabular}

Means with different superscript letters $(a, b, c)$ between dietary groups and $(A, B, C, D)$ between sampling time points differ significantly.

a SEM: Standard error of the means. ${ }^{b}$ Effect: The dietary treatment (D), time (S), and the interaction between dietary treatment $\times$ time $(\mathrm{D}$ $\times S$ ) effects were analyzed by ANOVA using a general linear model (GLM) for repeated measures, and post-hoc analysis was performed with appropriate use of Tukey's multiple range test. ${ }^{c}$ Fat corrected milk (FCM) in 6\%, ${ }^{\mathrm{d}}$ Energy corrected milk (ECM) yield, e Somatic Cell Counts. 


\subsection{Blood Fatty Acids Profile}

Significant differences in the FA profiles in blood plasma are depicted in Table 3. In Camelina-fed ewes, the proportions of several SFA were reduced. In detail, $\mathrm{C}_{14: 0}$ was significantly reduced $(p=0.001)$ in the Camelina-fed ewes. In compliance, the proportion of $\mathrm{C}_{15: 0}$ was reduced in the Camelina-fed ewes, but this reduction was significant $(p=0.025)$ only for the CSS16. Furthermore, the proportion of $\mathrm{C}_{16: 0}$ was found to be significantly reduced $(p=0.018)$ in the CSS11, while the proportion of $\mathrm{C}_{17: 0}$ was significantly reduced $(p<0.001)$ in the CSS6 and CSS11 compared to the CON and CSS16 groups. In addition, the proportions of $\mathrm{C}_{16: 1 \mathrm{n}-7}(p=0.007)$, and $\mathrm{C}_{18: 1 \text { cis-9 }}(p=0.003)$ were significantly reduced in the CSS16. The proportion of the $\mathrm{C}_{18: 2 \mathrm{n}-6}$ trans was significantly increased $(p=0.007)$ in the CSS16 compared to the CON and CSS11, while the proportion of $\mathrm{C}_{18: 2 \mathrm{n}-6 \text { cis was }}$ increased in the three CSS-fed ewes, but this increase was significant $(p<0.001)$ only in the CSS6 and CSS11. In addition, the proportion of $\mathrm{C}_{20: 3 \mathrm{n}-3}$ was significantly increased ( $p=$ $0.001)$ in the CSS6, the proportion of $C_{24: 1}$ n-9 was significantly enhanced $(p<0.001)$ in the CSS11 and CSS16 compared to the CSS6, while the proportion of $\mathrm{C}_{22: 6 \mathrm{n}-3}$ was significantly increased $(p<0.001)$ in the CSS11 and CSS16 compared to the CON and CSS6. Finally, the

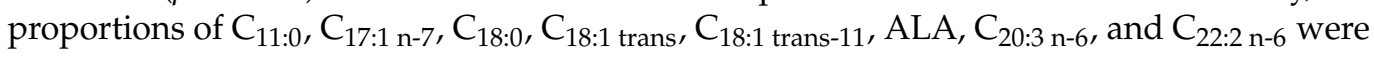
not significantly affected.

Table 3. The mean individual fatty acids (FA) (\% of total FA) in the blood plasma of ewes fed diets (CON, CSS6, CSS11, and CSS16) with different levels of Camelina seeds $(6 \%, 11 \%$, and $16 \%$ of concentrate) throughout the experimental period (15th, 30th, 45th and 60th experimental days).

\begin{tabular}{|c|c|c|c|c|c|c|c|c|c|c|c|c|c|}
\hline \multirow[t]{2}{*}{ Fatty Acid } & \multicolumn{4}{|c|}{ Dietary Treatments (D) } & \multicolumn{6}{|c|}{ Sampling Time (S) } & \multicolumn{3}{|c|}{ Effect $^{b}$} \\
\hline & $\mathrm{CON}$ & CSS6 & CSS11 & CSS16 & SEM $^{a}$ & 15 & 30 & 45 & 60 & SEM $^{a}$ & $\mathbf{D}$ & S & $\mathrm{D} \times \mathrm{S}$ \\
\hline $\mathrm{C}_{11: 0}$ & 0.29 & 0.24 & 0.59 & 0.31 & 0.29 & $0.53^{\mathrm{C}}$ & $0.21^{\mathrm{A}}$ & $0.33^{\mathrm{B}}$ & $0.36^{\mathrm{B}}$ & 0.55 & $<0.001$ & 0.001 & $<0.001$ \\
\hline $\mathrm{C}_{14: 0}$ & $1.02^{b}$ & $0.70^{\mathrm{a}}$ & $0.65^{\mathrm{a}}$ & $0.64^{\mathrm{a}}$ & 0.34 & $0.90^{\mathrm{B}}$ & $0.69^{\mathrm{A}}$ & $0.77 \mathrm{AB}$ & $0.64^{\mathrm{A}}$ & 0.61 & 0.001 & 0.022 & 0.174 \\
\hline $\mathrm{C}_{15: 0}$ & $0.37^{\mathrm{b}}$ & $0.29 \mathrm{ab}$ & $0.32^{a b}$ & $0.17^{\mathrm{a}}$ & 0.19 & 0.29 & 0.26 & 0.25 & 0.35 & 0.37 & 0.025 & 0.273 & 0.393 \\
\hline $\mathrm{C}_{16: 0}$ & $21.46^{\mathrm{b}}$ & $20.57^{\mathrm{ab}}$ & $19.83^{\text {a }}$ & $20.92^{a b}$ & 0.19 & $22.63^{C}$ & $20.53^{\text {B }}$ & $20.34^{\mathrm{AB}}$ & $19.28^{\mathrm{A}}$ & 0.34 & 0.018 & $<0.001$ & 0.001 \\
\hline$C_{16: 1 \mathrm{n}-7}$ & $1.06^{\mathrm{b}}$ & $0.76^{\mathrm{ab}}$ & $0.79 \mathrm{ab}$ & $0.55^{\mathrm{a}}$ & 0.42 & $1.12^{\mathrm{B}}$ & $0.66^{\mathrm{A}}$ & $0.67^{\mathrm{A}}$ & $0.70^{\mathrm{A}}$ & 0.79 & 0.007 & 0.001 & 0.655 \\
\hline $\mathrm{C}_{17: 0}$ & $2.40^{\mathrm{b}}$ & $1.73^{\mathrm{a}}$ & $1.39^{\mathrm{a}}$ & $2.66^{\mathrm{b}}$ & 0.10 & 2.41 & 2.21 & 2.15 & 1.42 & 0.25 & $<0.001$ & 0.006 & $<0.001$ \\
\hline $\mathrm{C}_{17: 1 \mathrm{n}-7}$ & 0.02 & 0.05 & 0.02 & 0.05 & 0.01 & 0.03 & 0.04 & 0.06 & 0.02 & 0.01 & 0.351 & 0.518 & 0.275 \\
\hline $\mathrm{C}_{18: 0}$ & 21.10 & 21.10 & 20.44 & 20.70 & 0.34 & $20.62^{\mathrm{AB}}$ & $20.03^{A}$ & $20.65^{\mathrm{AB}}$ & $22.05^{\text {B }}$ & 0.60 & 0.849 & 0.044 & 0.485 \\
\hline $\mathrm{C}_{18: 1 \text { trans }}$ & 0.15 & 0.19 & 0.29 & 0.27 & 0.03 & $0.04^{\mathrm{A}}$ & $0.17^{\mathrm{BC}}$ & $0.27^{\mathrm{C}}$ & $0.42^{\mathrm{D}}$ & 0.39 & 0.056 & $<0.001$ & 0.047 \\
\hline $\mathrm{C}_{18: 1 \text { trans-11 }}$ & 1.01 & 0.88 & 0.89 & 0.83 & 0.04 & $0.57^{\mathrm{A}}$ & $0.81^{\mathrm{B}}$ & $0.98^{\mathrm{B}}$ & $1.25^{\mathrm{C}}$ & 0.07 & 0.583 & $<0.001$ & 0.024 \\
\hline $\mathrm{C}_{18: 1 \text { cis-9 }}$ & $15.91^{\mathrm{b}}$ & $15.03^{a b}$ & $14.66^{\mathrm{ab}}$ & $12.55^{\mathrm{a}}$ & 0.30 & 14.40 & 13.75 & 14.84 & 15.17 & 0.59 & 0.003 & 0.356 & 0.020 \\
\hline$C_{18: 2 \mathrm{n}-6 \text { trans }}$ & $0.03^{\mathrm{a}}$ & $0.05^{\mathrm{ab}}$ & $0.02^{\mathrm{a}}$ & $0.10^{b}$ & 0.05 & $0.00^{\mathrm{A}}$ & $0.00^{\mathrm{A}}$ & $0.04^{\mathrm{B}}$ & $0.17^{\mathrm{C}}$ & 0.13 & 0.007 & $<0.001$ & 0.014 \\
\hline$C_{18: 2 \mathrm{n}-6 \text { cis }}$ & $19.26^{\mathrm{a}}$ & $23.13^{b}$ & $21.66^{b}$ & $20.98^{a b}$ & 0.27 & $22.51^{\mathrm{C}}$ & $19.97 \mathrm{~A}$ & $20.99 \mathrm{AB}$ & $21.57^{\mathrm{BC}}$ & 0.54 & $<0.001$ & 0.002 & 0.028 \\
\hline$C_{18: 3 n-3}$ & 2.71 & 3.28 & 3.04 & 3.00 & 0.09 & $1.97^{\mathrm{A}}$ & $2.67^{\text {в }}$ & $3.31^{\mathrm{C}}$ & $4.07^{\mathrm{D}}$ & 0.31 & 0.098 & $<0.001$ & 0.062 \\
\hline$C_{20: 3 n-6}$ & 0.18 & 0.06 & 0.13 & 0.17 & 0.02 & $0.07^{\mathrm{A}}$ & $0.07^{\mathrm{A}}$ & $0.16^{\mathrm{B}}$ & $0.24^{\text {B }}$ & 0.15 & 0.428 & 0.044 & 0.101 \\
\hline$C_{20: 3 n-3}$ & $3.21^{\mathrm{a}}$ & $3.80^{\mathrm{b}}$ & $3.36^{\mathrm{a}}$ & $3.20^{\mathrm{a}}$ & 0.08 & $4.10^{\mathrm{D}}$ & $3.67^{\mathrm{C}}$ & $3.10^{\mathrm{B}}$ & $2.70^{\mathrm{A}}$ & 0.14 & 0.001 & $<0.001$ & 0.037 \\
\hline$C_{22: 2 n-6}$ & 0.84 & 0.94 & 0.92 & 0.84 & 0.03 & $0.58^{\mathrm{A}}$ & $0.88^{\text {B }}$ & $0.98^{\mathrm{BC}}$ & $1.11^{\mathrm{C}}$ & 0.89 & 0.486 & $<0.001$ & 0.728 \\
\hline$C_{24: 1 \mathrm{n}-9}$ & $8.24^{a b}$ & $6.44^{\mathrm{a}}$ & $9.85^{b}$ & $10.80^{b c}$ & 0.34 & $6.98^{\mathrm{A}}$ & $12.20^{\mathrm{C}}$ & $8.82^{\mathrm{B}}$ & $7.34 \mathrm{~A}$ & 0.62 & $<0.001$ & $<0.001$ & $<0.001$ \\
\hline$C_{22: 6 n-3}$ & $0.47^{\mathrm{a}}$ & $0.61^{a}$ & $1.00^{b}$ & $1.02^{b}$ & 0.05 & $0.16^{\mathrm{A}}$ & $1.04^{\mathrm{B}}$ & $0.98^{\mathrm{B}}$ & $0.92^{\mathrm{B}}$ & 0.07 & $<0.001$ & $<0.001$ & $<0.001$ \\
\hline
\end{tabular}

Means with different superscript letters $(\mathrm{a}, \mathrm{b}, \mathrm{c})$ between dietary groups and $(\mathrm{A}, \mathrm{B}, \mathrm{C}, \mathrm{D})$ between sampling time points differ significantly.

a SEM: Standard error of the means. ${ }^{b}$ Effect: The dietary treatment (D), time (S), and the interaction between dietary treatment $\times$ time (D $\times$ S) effects were analyzed by ANOVA using a general linear model (GLM) for repeated measures, and post-hoc analysis was performed with appropriate use of Tukey's multiple range test.

\subsection{Milk Fatty Acids Profile}

The inclusion of Camelina seed levels in ewes' diets significantly $(p<0.001)$ reduced the SFA content (Table 4). In detail, the total SCFA and MCFA content and, more specifically the proportion of $C_{8: 0}, C_{10: 0}, C_{11: 0}, C_{12: 0}$, and $C_{16: 0}$ were linearly reduced $(p<0.001)$ in Camelina-fed ewes (Table 4). The MCFA content was significantly increased on the 30th sampling time compared to the 15th $(p=0.045)$. The proportions of $\mathrm{C}_{6: 0}(p<0.001)$ and $\mathrm{C}_{15: 0}(p<0.001)$ were significantly reduced in the CSS11 and CSS16, while that of $\mathrm{C}_{14: 0}$ found significantly reduced ( $p=0.005)$ in the CSS16. In contrast, the proportion of $\mathrm{C}_{4: 0}$ was significantly increased $(p=0.174)$ in the CSS6, the proportion of $\mathrm{C}_{17: 0}$ was significantly increased $(p=0.011)$ in the CSS6 compared to the CSS11, and the proportion of $\mathrm{C}_{22: 0}$ was significantly increased $(p<0.001)$ in the CSS-fed ewes. Additionally, supplementing 
Camelina seeds in ewes' diets significantly increased $(p<0.001)$ the proportion of $\mathrm{C}_{18: 0}$ and $\mathrm{C}_{20: 0}$ among the CSS groups and compared to the CON. Regarding $\mathrm{C}_{18: 0}$, the same trend was reported on the 15th sampling time compared to the 30th and the 60th $(p=0.002)$.

In addition, the total content of MUFA was linearly increased $(p<0.001)$ among the Camelina-fed ewes (Table 4). In detail, supplementing ewes' diets with Camelina seeds at $11 \%$, significantly increased $(p<0.001)$ the proportion of $C_{18: 1}$ trans-11, while supplementing with $16 \%$ almost threefold significantly increased $(p<0.001)$ its proportion. However, milk

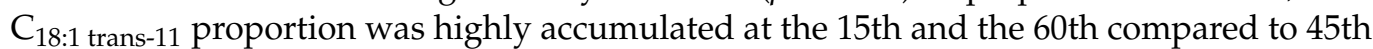
experimental day $(p=0.046)$. In contrast, the proportions of $\mathrm{C}_{14: 1}(p<0.001), \mathrm{C}_{15: 1}(p=$ $0.001)$ and $\mathrm{C}_{17: 1 \mathrm{n}-7}(p<0.001)$ were reduced in the CSS11 and CSS16, while the proportion of $\mathrm{C}_{16: 1 \mathrm{n}-7}$ was significantly reduced $(p<0.001)$ in the three CSS-fed ewes (Table 4$)$. The proportions of total $C_{18: 1 \text { trans }}(p<0.001), C_{18: 1 \text { cis-9 }}(p<0.001)$, and $C_{20: 1 ~ n-9}(p<0.001)$ were linearly increased among the Camelina-fed ewes compared to the CON (Table 4).

Furthermore, supplementing Camelina seeds in ewes' diets linearly increased the total content of LCFA $(p<0.001)$, UFA $(p<0.001)$, and PUFA $(p<0.001)$, with the latter being even two-fold increased it in the CSS16 (Table 4). This increase in PUFA was reported through the four sampling times but was significant $(p=0.005)$ only on the final sampling, resulting in a significant interaction $(p=0.013)$ between the dietary treatment and sampling time. In details, the proportions of $\mathrm{C}_{18: 2 \mathrm{n}-6 \text { trans }}(p<0.001)$, ALA $(p<0.001), \mathrm{C}_{18: 2 \text { cis-9, trans-11 }}$ (CLA) $(p<0.001), \mathrm{C}_{18: 2 \text { trans-10, cis-12 }}$ (CLA) $(p<0.001)$ and arachidonic acid $\left(\mathrm{C}_{20: 4 \mathrm{n}-6}\right)(p<0.001)$ were linearly increased among the Camelina-fed ewes and compared to the CON (Table 4). In fact, in the CSS16, the proportion of ALA was two-fold raised, while the proportion

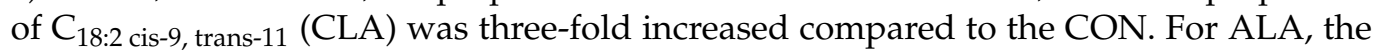
same significant trend was observed on the 60th compared to the 30th experimental day $(p=0.010)$, while for $C_{18: 2 \text { cis-9, trans-11 this increase was observed on the } 45 \text { th and } 60 \text { th }}$ compared to the 15th and the 30th experimental day $(p<0.001)$ and led to interaction between the dietary treatment and the sampling time $(p=0.003)$. Interestingly, the apparent transfer efficiency rate of ALA from the diets to milk was $5.8 \%, 4 \%$, and $3,6 \%$ for the CSS6-, CSS11-, and CSS16-fed ewes, respectively. Still, the proportion of $\mathrm{C}_{18: 2 \mathrm{n}-6 \text { cis was }}$ significantly increased $(p=0.001)$ in the Camelina-fed ewes, while the proportion of $C_{20: 3} \mathrm{n}-3$ was significantly reduced $(p<0.001)$ in the CSS11 and CSS16 compared to the CON and CSS6 (Table 4). Finally, the SFA/UFA was linearly significantly decreased $(p<0.001)$ in the CSS-fed ewes compared to the CON.

Both $\omega 6$ and $\omega 3$ contents were linearly increased $(p<0.001)$ among the Camelinafed ewes. Noteworthy, the $\omega 6 / \omega 3$ was significantly reduced $(p<0.001)$ in the CSSfed ewes (Table 4). In our study, atherogenicity (AI) and thrombogenic (TI) indexes were linearly decreased ( $p=0.006$ and $p<0.001$, respectively) among the four dietary treatments (Table 4). In addition, the health-promoting index (HPI) was linearly improved among the four dietary treatments $(p<0.001)$. Concerning the $\Delta-9$ desaturases indexes, $\mathrm{C}_{14: 1} / \mathrm{C}_{14: 0}$ was not affected. In contrast, $\mathrm{C}_{16: 1} / \mathrm{C}_{16: 0}$ was significantly increased $(p=0.024)$ in the CSS16, $C_{18: 1 \text { cis-9 }} / \mathrm{C}_{18: 0}$ was also increased $(p<0.001)$ in the CSS11 and CSS16, and

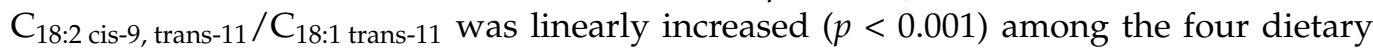
treatments as well (Table 4$)$.

Pearson's correlation led us to the conclusion that ALA was positively correlated with $C_{18: 1 \text { cis-9 }}\left(R^{2}=0.499 ; p<0.01\right), C_{18: 1 \text { trans }}\left(R^{2}=0.381 ; p<0.01\right), C_{18: 2 \text { trans-11, cis-9 }}\left(R^{2}=0.455\right.$; $p<0.01)$, MUFA $\left(R^{2}=0.492 ; p<0.01\right)$, and PUFA $\left(R^{2}=0.797 ; p<0.01\right)$. On the other hand, ALA was negatively correlated with $C_{16: 0}\left(R^{2}=0.396 ; p<0.01\right)$, SFA $\left(R^{2}=0.617 ; p<0.01\right)$, and MCFA $\left(R^{2}=0.492 ; p<0.01\right)$ (Figure 1$)$. 
Table 4. The mean individual fatty acids (FA) (\% of total FA), grouped FA, FA health indices, and $\Delta-9$ desaturase indices in the milk of ewes fed diets (CON, CSS6, CSS11, and CSS16) with different levels of Camelina seeds $(6 \%, 11 \%$, and $16 \%$ of concentrate) throughout the experimental period (15th, 30th, 45th and 60th experimental days).

\begin{tabular}{|c|c|c|c|c|c|c|c|c|c|c|c|c|c|}
\hline \multirow[t]{2}{*}{ Fatty acid } & \multicolumn{4}{|c|}{ Dietary Treatment (D) } & \multicolumn{6}{|c|}{ Sampling Time (S) } & \multicolumn{3}{|c|}{ Effect $^{\mathrm{b}}$} \\
\hline & $\mathrm{CON}$ & CSS6 & CSS11 & CSS16 & SEM $^{a}$ & 15 & 30 & 45 & 60 & SEM $^{a}$ & $\mathbf{D}$ & $\mathrm{S}$ & $\mathrm{D} \times \mathrm{S}$ \\
\hline $\mathrm{C}_{4: 0}$ & $4.23^{\mathrm{a}}$ & $4.45^{\mathrm{b}}$ & $4.32 \mathrm{ab}$ & $4.40^{\mathrm{ab}}$ & 0.070 & $4.48^{\mathrm{B}}$ & $4.20^{\mathrm{A}}$ & $4.40^{\mathrm{AB}}$ & $4.32 \mathrm{AB}$ & 0.069 & 0.174 & 0.042 & $<0.001$ \\
\hline $\mathrm{C}_{6: 0}$ & $3.33^{c}$ & $3.18^{\mathrm{c}}$ & $2.84^{b}$ & $2.29^{a}$ & 0.053 & 2.96 & 2.84 & 2.93 & 2.91 & 0.052 & $<0.001$ & 0.476 & $<0.001$ \\
\hline $\mathrm{C}_{8: 0}$ & $3.08^{\mathrm{d}}$ & $2.80^{\mathrm{c}}$ & $2.39^{b}$ & $1.72^{\mathrm{a}}$ & 0.057 & 2.54 & 2.48 & 2.49 & 2.48 & 0.058 & $<0.001$ & 0.872 & 0.079 \\
\hline $\mathrm{C}_{10: 0}$ & $9.53^{d}$ & $7.88^{\mathrm{c}}$ & $6.56^{\mathrm{b}}$ & $4.55^{\mathrm{a}}$ & 0.187 & 7.17 & 7.13 & 7.08 & 7.15 & 0.176 & $<0.001$ & 0.981 & 0.077 \\
\hline$C_{11: 0}$ & $0.37^{\mathrm{d}}$ & $0.32^{c}$ & $0.28^{\mathrm{b}}$ & $0.19^{\mathrm{a}}$ & 0.009 & $0.27^{\mathrm{A}}$ & $0.29 \mathrm{AB}$ & 0.29 АВ & $0.31^{\mathrm{B}}$ & 0.009 & $<0.001$ & 0.010 & 0.093 \\
\hline $\mathrm{C}_{12: 0}$ & $5.15^{\mathrm{d}}$ & $4.22^{c}$ & $3.72^{b}$ & $2.91^{\mathrm{a}}$ & 0.099 & 3.97 & 4.09 & 3.80 & 3.94 & 0.089 & $<0.001$ & 0.334 & 0.109 \\
\hline$C_{14: 0}$ & $12.64^{\mathrm{b}}$ & $11.43^{\mathrm{ab}}$ & $11.92^{b}$ & $10.02^{\mathrm{a}}$ & 0.504 & 11.00 & 12.49 & 11.04 & 11.48 & 0.380 & 0.005 & 0.161 & 0.211 \\
\hline $\mathrm{C}_{14: 1}$ & $0.42^{\mathrm{c}}$ & $0.40^{\mathrm{bc}}$ & $0.38^{\mathrm{ab}}$ & $0.37^{\mathrm{a}}$ & 0.007 & $0.37^{\mathrm{A}}$ & $0.40^{\mathrm{B}}$ & $0.41^{\mathrm{B}}$ & $0.38^{\mathrm{AB}}$ & 0.008 & $<0.001$ & 0.002 & 0.174 \\
\hline $\mathrm{C}_{15: 0}$ & $0.92^{b}$ & $0.89^{\mathrm{b}}$ & $0.81^{\mathrm{a}}$ & $0.80^{a}$ & 0.014 & $0.83^{\mathrm{A}}$ & $0.89^{\mathrm{B}}$ & $0.86^{\mathrm{AB}}$ & $0.83^{\mathrm{A}}$ & 0.014 & $<0.001$ & 0.006 & 0.889 \\
\hline$C_{15: 1}$ & $0.28^{\mathrm{b}}$ & $0.28^{\mathrm{b}}$ & $0.25^{\mathrm{a}}$ & $0.25^{\mathrm{a}}$ & 0.007 & $0.27^{\text {в }}$ & $0.28^{\mathrm{B}}$ & $0.28^{\text {B }}$ & 0.24 A & 0.007 & 0.001 & $<0.001$ & 0.399 \\
\hline $\mathrm{C}_{16: 0}$ & $28.55^{\mathrm{d}}$ & $24.95^{\mathrm{c}}$ & $23.40^{\mathrm{b}}$ & $22.26^{\mathrm{a}}$ & 0.271 & $24.27^{\text {A }}$ & $24.39^{\mathrm{A}}$ & $25.50^{\mathrm{B}}$ & $24.99 \mathrm{AB}$ & 0.280 & $<0.001$ & 0.011 & 0.500 \\
\hline$C_{16: 1 \mathrm{n}-7}$ & $1.07^{\mathrm{b}}$ & $0.96^{\mathrm{a}}$ & $0.90^{\mathrm{a}}$ & $0.92^{\mathrm{a}}$ & 0.028 & $0.87^{\mathrm{A}}$ & $0.91 \mathrm{AB}$ & $0.99 \mathrm{BC}$ & $1.07^{\mathrm{C}}$ & 0.028 & $<0.001$ & $<0.001$ & 0.004 \\
\hline $\mathrm{C}_{17: 0}$ & $0.52^{a b}$ & $0.53^{\mathrm{b}}$ & $0.49^{a}$ & $0.50^{\mathrm{ab}}$ & 0.009 & $0.54^{\mathrm{C}}$ & $0.52^{\mathrm{BC}}$ & $0.49 \mathrm{AB}$ & $0.48^{\mathrm{A}}$ & 0.010 & 0.011 & $<0.001$ & 0.019 \\
\hline$C_{17: 1 \mathrm{n}-7}$ & $0.25^{\mathrm{b}}$ & $0.25^{b}$ & $0.21^{\mathrm{a}}$ & $0.20^{\mathrm{a}}$ & 0.007 & 0.23 & 0.23 & 0.23 & 0.22 & 0.007 & $<0.001$ & 0.525 & 0.014 \\
\hline $\mathrm{C}_{18: 0}$ & $7.68^{a}$ & $8.86^{b}$ & $9.10^{\mathrm{b}}$ & $9.96^{c}$ & 0.119 & $9.42^{\mathrm{B}}$ & $8.83^{\mathrm{A}}$ & $9.09 \mathrm{AB}$ & $8.26^{\mathrm{A}}$ & 0.233 & $<0.001$ & 0.002 & 0.602 \\
\hline $\mathrm{C}_{18: 1 \text { trans }}$ & $0.52^{\mathrm{a}}$ & $1.07^{\mathrm{b}}$ & $1.41^{\mathrm{b}}$ & $1.57^{\mathrm{b}}$ & 0.046 & $1.12 \mathrm{AB}$ & $1.20^{\mathrm{B}}$ & $1.15^{\mathrm{AB}}$ & $1.08^{\mathrm{A}}$ & 0.039 & $<0.001$ & 0.169 & 0.021 \\
\hline $\mathrm{C}_{18: 1 \text { trans- } 11}$ & $0.69^{a}$ & $0.86^{\mathrm{ab}}$ & $1.13^{\mathrm{b}}$ & $1.85^{\mathrm{c}}$ & 0.105 & $1.27^{\mathrm{B}}$ & $1.01 \mathrm{AB}$ & $0.95^{\mathrm{A}}$ & $1.31^{\mathrm{B}}$ & 0.084 & $<0.001$ & 0.046 & 0.015 \\
\hline $\mathrm{C}_{18: 1 \text { cis-9 }}$ & $16.58^{\mathrm{a}}$ & $20.38^{b}$ & $21.77^{\mathrm{c}}$ & $24.86^{\mathrm{d}}$ & 0.279 & 21.34 & 20.59 & 20.80 & 20.85 & 0.553 & $<0.001$ & 0.509 & 0.219 \\
\hline$C_{18: 2 n-6 \text { trans }}$ & $0.19^{a}$ & $0.55^{\mathrm{b}}$ & $0.87^{\mathrm{c}}$ & $1.21^{\mathrm{d}}$ & 0.030 & $0.68^{\mathrm{A}}$ & $0.70 \mathrm{AB}$ & $0.65^{\mathrm{A}}$ & $0.80^{\mathrm{B}}$ & 0.030 & $<0.001$ & 0.011 & 0.082 \\
\hline$C_{18: 2 \mathrm{n}-6 \text { cis }}$ & $2.70^{\mathrm{a}}$ & $2.90^{\mathrm{b}}$ & $2.95^{b}$ & $3.09^{b}$ & 0.064 & 2.90 & 2.88 & 2.91 & 2.95 & 0.058 & 0.001 & 0.849 & 0.218 \\
\hline $\mathrm{C}_{20: 0}$ & $0.11^{\mathrm{a}}$ & $0.58^{\mathrm{b}}$ & $0.85^{c}$ & $1.12^{\mathrm{d}}$ & 0.017 & 0.65 & 0.67 & 0.66 & 0.68 & 0.018 & $<0.001$ & 0.605 & 0.006 \\
\hline $\mathrm{C}_{18: 3 \mathrm{n}-3}$ & $0.54^{a}$ & $0.84^{b}$ & $1.04^{\mathrm{c}}$ & $1.26^{\mathrm{d}}$ & 0.028 & $0.92 \mathrm{AB}$ & $0.87^{\mathrm{A}}$ & $0.90^{\mathrm{AB}}$ & $0.97^{\mathrm{B}}$ & 0.028 & $<0.001$ & 0.010 & 0.361 \\
\hline $\mathrm{C}_{18: 2 \text { cis- }-9 \text {, trans- } 11}$ & $0.45^{\mathrm{a}}$ & $0.68^{b}$ & $1.03^{c}$ & $1.65^{\mathrm{d}}$ & 0.048 & $0.82^{\mathrm{A}}$ & $0.85^{\mathrm{A}}$ & $1.06^{\mathrm{B}}$ & $1.08^{\mathrm{B}}$ & 0.05 & $<0.001$ & $<0.001$ & 0.003 \\
\hline $\mathrm{C}_{20: 1 \mathrm{n}-9}$ & $0.00^{\mathrm{a}}$ & $0.37^{\mathrm{b}}$ & $0.63^{c}$ & $0.88^{\mathrm{d}}$ & 0.036 & $0.57^{\mathrm{C}}$ & $0.59^{\mathrm{C}}$ & $0.28^{\mathrm{A}}$ & $0.44^{\text {B }}$ & 0.032 & $<0.001$ & $<0.001$ & $<0.001$ \\
\hline $\mathrm{C}_{18: 2 \text { trans }-10 \text {, cis- } 12}$ & $0.00^{\mathrm{a}}$ & $0.00^{\mathrm{a}}$ & $0.01^{b}$ & $0.06^{\mathrm{b}}$ & 0.006 & $0.004^{\mathrm{A}}$ & $0.03^{\mathrm{B}}$ & $0.005^{\mathrm{A}}$ & $0.03^{\mathrm{B}}$ & 0.005 & $<0.001$ & $<0.001$ & $<0.001$ \\
\hline $\begin{array}{l}18: 2 \text { trans-10, cls-12 } \\
\mathrm{C}_{22: 0}\end{array}$ & $0.09^{a}$ & $0.20^{\mathrm{b}}$ & $0.19^{b}$ & $0.25^{c}$ & 0.010 & $0.14^{\mathrm{A}}$ & $0.20^{\mathrm{BC}}$ & $0.21^{\mathrm{C}}$ & $0.17^{\text {в }}$ & 0.009 & $<0.001$ & $<0.001$ & $<0.001$ \\
\hline $\mathrm{C}_{20: 3 \mathrm{n}-3}$ & $0.23^{b}$ & $0.21^{\mathrm{b}}$ & $0.20^{\mathrm{a}}$ & $0.18^{a}$ & 0.004 & $0.22^{\mathrm{B}}$ & $0.20^{\mathrm{A}}$ & $0.20^{\mathrm{A}}$ & $0.20^{\mathrm{A}}$ & 0.004 & $<0.001$ & 0.001 & 0.442 \\
\hline $\mathrm{C}_{20: 4 \mathrm{n}-6}$ & $0.00^{\mathrm{a}}$ & $0.02^{\mathrm{a}}$ & $0.31^{\mathrm{b}}$ & $0.61^{\mathrm{c}}$ & 0.015 & $0.18^{\mathrm{A}}$ & $0.22^{\mathrm{AB}}$ & $0.25^{\mathrm{BC}}$ & $0.29^{\mathrm{C}}$ & 0.016 & $<0.001$ & $<0.001$ & $<0.001$ \\
\hline \multicolumn{14}{|c|}{ Grouped Fatty Acids } \\
\hline SCFA & $20.54^{d}$ & $18.62^{\mathrm{c}}$ & $16.39^{b}$ & $13.15^{\mathrm{a}}$ & 0.303 & 17.40 & 16.94 & 17.18 & 17.18 & 0.300 & $<0.001$ & 0.744 & 0.001 \\
\hline MCFA & $47.28^{d}$ & $41.51^{\mathrm{c}}$ & $39.85^{\mathrm{b}}$ & $36.00^{\text {a }}$ & 0.420 & $40.09^{\mathrm{A}}$ & $41.86^{\mathrm{B}}$ & $41.32 \mathrm{AB}$ & $41.36^{\mathrm{AB}}$ & 0.442 & $<0.001$ & 0.075 & 0.045 \\
\hline LCFA & $8.19^{\mathrm{a}}$ & $9.80^{\mathrm{b}}$ & $10.45^{c}$ & $11.60^{\mathrm{d}}$ & 0.207 & $10.61^{\text {в }}$ & $9.88^{\mathrm{AB}}$ & 10.12 АВ & $9.43^{\mathrm{A}}$ & 0.218 & $<0.001$ & 0.004 & 0.488 \\
\hline MUFA & $19.78^{\text {a }}$ & $24.68^{\mathrm{b}}$ & $26.68^{c}$ & $30.90^{\mathrm{d}}$ & 0.349 & 26.02 & $\begin{array}{l}.00 \\
25.36\end{array}$ & 25.18 & 25.49 & 0.694 & $<0.001$ & 0.464 & 0.003 \\
\hline PUFA & $4.12^{\mathrm{a}}$ & $5.19^{\mathrm{b}}$ & $6.44^{\mathrm{c}}$ & $8.11^{\mathrm{d}}$ & 0.129 & $5.74^{\mathrm{A}}$ & $5.76^{\mathrm{A}}$ & $5.98^{\mathrm{A}}$ & $6.38^{\mathrm{B}}$ & 0.254 & $<0.001$ & 0.005 & 0.013 \\
\hline SFA & $76.01 \mathrm{~d}$ & $69.93^{c}$ & $66.69^{\mathrm{b}}$ & $60.75^{a}$ & 0.412 & 68.10 & 68.68 & 68.62 & $\begin{array}{l}0.00 \\
67.97\end{array}$ & 0.440 & $<0.001$ & 0.598 & 0.001 \\
\hline UFA & $23.90^{\text {a }}$ & $29.87^{b}$ & $33.12^{c}$ & $39.01^{\mathrm{d}}$ & 0.412 & 31.76 & 31.12 & 31.16 & 31.86 & 0.438 & $<0.001$ & 0.526 & 0.001 \\
\hline SFA/UFA & $3.18^{\mathrm{d}}$ & $2.34^{\mathrm{c}}$ & $2.01^{\mathrm{b}}$ & $1.56^{\mathrm{a}}$ & 0.048 & 2.25 & 2.37 & 2.29 & 2.31 & 0.049 & $<0.001$ & 0.504 & 0.005 \\
\hline$\omega 6$ & $2.91^{\mathrm{a}}$ & $3.46^{\mathrm{b}}$ & $4.14^{c}$ & $4.91^{\mathrm{d}}$ & 0.069 & $3.76^{\mathrm{A}}$ & $3.79^{\mathrm{A}}$ & $3.82^{\mathrm{A}}$ & $4.04^{\mathrm{B}}$ & 0.136 & $<0.001$ & 0.063 & 0.005 \\
\hline$\omega 3$ & $0.77^{\mathrm{a}}$ & $1.05^{\mathrm{b}}$ & $1.24^{\mathrm{c}}$ & $1.44^{\mathrm{d}}$ & 0.023 & $1.14^{\mathrm{AB}}$ & $1.07 \mathrm{~A}$ & $1.10^{\mathrm{A}}$ & $1.19^{\text {в }}$ & 0.361 & $<0.001$ & 0.024 & 0.341 \\
\hline$\omega 6 / \omega 3$ & $3.78^{b}$ & $3.30^{\mathrm{a}}$ & $3.34^{\mathrm{a}}$ & $3.41^{\mathrm{a}}$ & 0.038 & $3.39^{\mathrm{A}}$ & $3.59^{\mathrm{B}}$ & $3.56^{\mathrm{AB}}$ & $3.46^{\mathrm{AB}}$ & 0.074 & $<0.001$ & 0.189 & 0.628 \\
\hline \multicolumn{14}{|c|}{ Fatty Acids Health Indices } \\
\hline $\mathrm{AI}$ & $3.55^{\mathrm{a}}$ & $2.54^{\mathrm{b}}$ & $2.16^{\mathrm{c}}$ & $1.70^{\mathrm{d}}$ & 0.056 & $2.40^{\mathrm{A}}$ & $2.53^{\mathrm{B}}$ & $2.46^{\mathrm{AB}}$ & $2.56^{\mathrm{B}}$ & 0.555 & 0.006 & 0.101 & 0.003 \\
\hline $\mathrm{TI}$ & $3.52^{c}$ & $2.60^{b}$ & $2.36^{\mathrm{b}}$ & $1.90^{\mathrm{a}}$ & 0.054 & 2.51 & 2.69 & 2.61 & 2.56 & 0.107 & $<0.001$ & 0.294 & 0.040 \\
\hline HPI & $0.28^{a}$ & $0.39^{b}$ & $0.46^{\mathrm{c}}$ & $0.58^{\mathrm{d}}$ & 0.010 & $0.44^{\mathrm{A}}$ & $0.41^{\mathrm{T}}$ & $0.42^{\mathrm{A}}$ & $0.43^{\mathrm{A}}$ & 0.020 & $<0.001$ & 0.493 & 0.005 \\
\hline \multicolumn{14}{|c|}{$\Delta-9$ Desaturase Indices } \\
\hline $\mathrm{C}_{14: 1} / \mathrm{C}_{14: 0}$ & 0.033 & 0.035 & 0.032 & 0.037 & 0.002 & 0.03 & 0.04 & 0.03 & 0.04 & 0.002 & 0.520 & 0.198 & 0.526 \\
\hline $\mathrm{C}_{16: 1} / \mathrm{C}_{16: 0}$ & $0.037^{\text {a }}$ & $0.038^{\mathrm{ab}}$ & $0.038^{\mathrm{ab}}$ & $0.041^{\mathrm{b}}$ & 0.001 & $0.036^{\mathrm{A}}$ & $0.037^{\mathrm{A}}$ & $0.038^{\mathrm{AB}}$ & $0.042^{\mathrm{B}}$ & 0.001 & 0.024 & $<0.001$ & 0.010 \\
\hline$C_{18: 1 \text { cis-9 }} / C_{18: 0}$ & $2.16^{\mathrm{a}}$ & $2.30^{a b}$ & $2.39 \mathrm{bc}$ & $2.50^{\mathrm{c}}$ & 0.263 & $2.28^{\mathrm{A}}$ & $2.35^{\mathrm{A}}$ & $2.34 \mathrm{~A}$ & $2.59^{\mathrm{B}}$ & 0.177 & $<0.001$ & 0.366 & 0.388 \\
\hline $\begin{array}{c}\mathrm{C}_{18: 2 \text { cis-9 trans-11 }} / \\
\mathrm{C}_{18: 1} \text { trans-11 }\end{array}$ & $0.65^{a}$ & $0.79^{b}$ & $0.91^{\mathrm{d}}$ & $0,89^{\mathrm{c}}$ & 0.025 & $0.64^{\mathrm{A}}$ & $0.83^{\mathrm{B}}$ & $1.06^{\mathrm{C}}$ & $0.94^{\mathrm{B}}$ & 0.029 & $<0.001$ & $<0.001$ & $<0.001$ \\
\hline
\end{tabular}

Means with different superscript letters $(a, b, c)$ between dietary groups and (A, B, C, D) between sampling time points differ significantly.

a SEM: Standard error of the means. ${ }^{b}$ Effect: The dietary treatment (D), time (S), and the interaction between dietary treatment $\times$ time (D

$\times$ S) effects were analyzed by ANOVA using a general linear model (GLM) for repeated measures, and posthoc analysis was performed with appropriate use of Tukey's multiple range test.

Figure 2A,B depicts the discriminant plots of the four dietary treatments $(\mathrm{CON}$; blue $\square$, CSS6; green $\bigcirc$, CSS11; red $\diamond$, and CSS16; black $\triangle$ ) throughout the experimental period based on milk individual fatty acids, grouped fatty acids, fatty acids health indices, and $\Delta-9$ desaturase indices. By inserting the independent variables together, the proportions of the samples that were correctly classified were $96.3 \%$, while Wilks's $\lambda$ was observed at 0.009 for Function $1(p<0.001)$ and at 0.306 for Function $2(p<0.001)$ (Figure 2A). CON variables were significantly (Function 1 ) different from those of the Camelina-fed groups, while CSS groups were progressively allocated in the right half (Figure 2A). Applying a stepwise method aiming to avoid any multicollinearity, a higher correct classification 
was achieved $(97.4 \%)$. Wilks's $\lambda$ was observed at 0.008 for Function $1(p<0.001)$ and at 0.238 for Function $2(p<0.001)$, while the proportion of $\mathrm{C}_{20: 0}, \mathrm{C}_{20: 4 \mathrm{n}-6}, \mathrm{C}_{18: 1 \text { trans }}, \mathrm{C}_{22: 0}$, $C_{18: 1 \text { trans-11 }}, C_{11: 0}, C_{18: 2}$ n-6 $, C_{14: 0}, C_{18: 0}$, and $C_{18: 2}$ trans-10, cis-12 were the variables (10 out of 19) that contributed the most (Figure $2 \mathrm{~B}$ ). CON variables were significantly (Function 1 ) different from those of the Camelina-fed groups (Figure 2B).
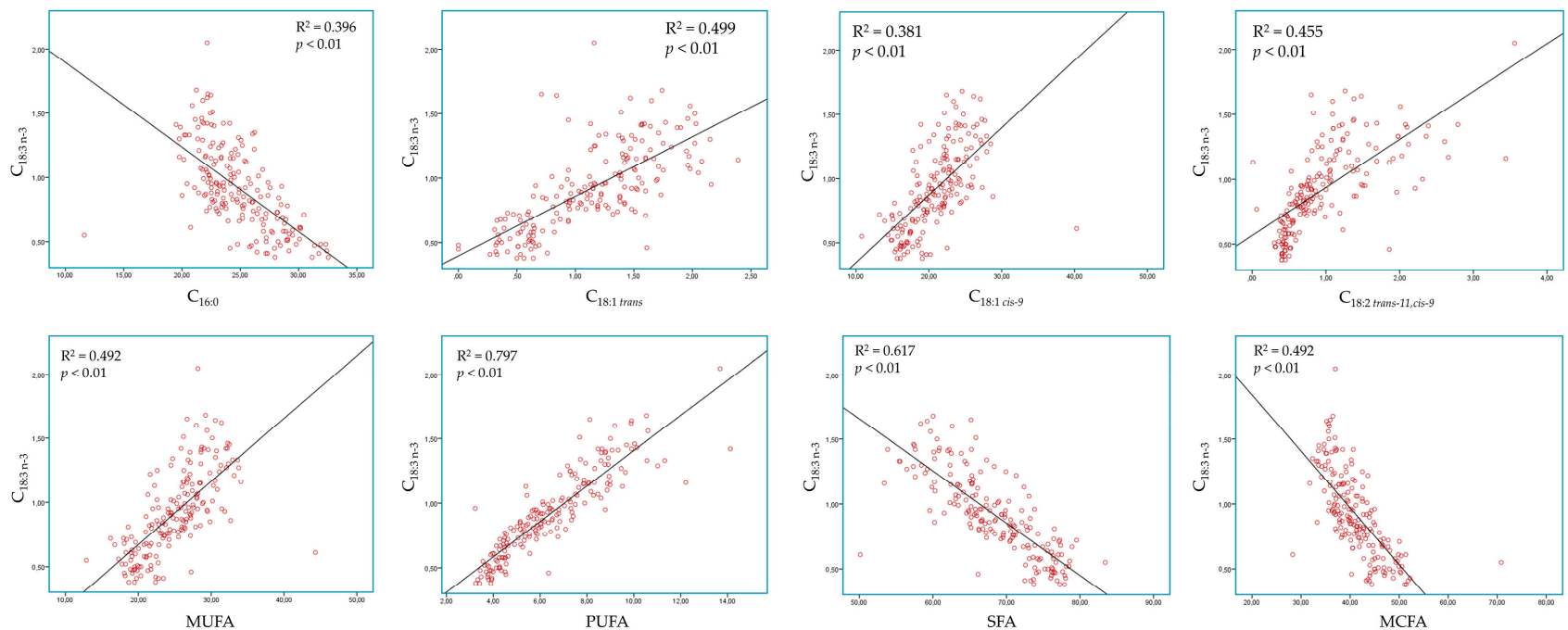

Figure 1. Pearson correlations concerning milk alpha linolenic acid (C18:3 n-3).
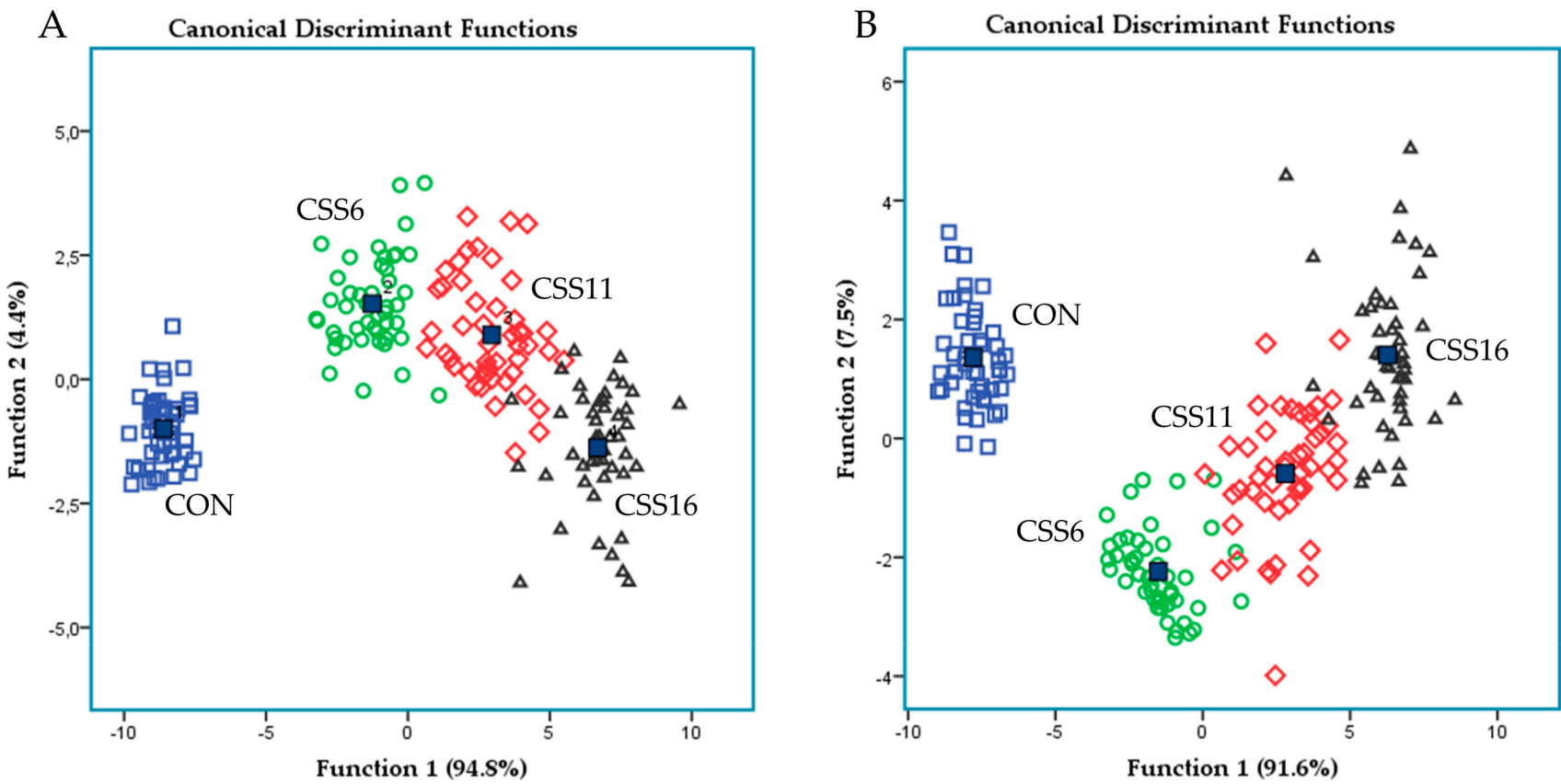

Figure 2. Discriminant plots separating (A) the four dietary treatments (CON; blue $\square$, CSS6; green $\bigcirc$, CSS11; red $\diamond$, and CSS16; black $\triangle$ ) according to pooled data of four sampling times (15th, 30th, 45th, and 60th experimental day) that entered independent variables of milk individual fatty acids together, grouped fatty acids, fatty acids health indices, and $\Delta-9$ desaturase indices and (B) discriminating the four dietary treatments (CON; blue $\square$, CSS6; green $\bigcirc, \operatorname{CSS} 11$; red $\diamond$, and CSS16; black $\triangle$ ) based on a step-wise method. 


\subsection{Blood Plasma and Milk Oxidative Status}

The mean differences of the antioxidant enzyme activities, the total antioxidant capacity, and the oxidative status of blood plasma and milk are presented in Table 5. Concerning the antioxidant enzyme activities in ewe's blood plasma, SOD activity was reported significantly higher $(p=0.014)$ in the CSS16. Still, an upward trend was observed in SOD activity from the 15th to the 60th experimental day $(p<0.001)$. Statistically significant enhanced activity $(p=0.006)$ was also observed in CAT in the CSS11- and CSS16-fed ewes, with the peak of activity being reported in the 30th sampling day $(p=0.052)$. However, we did not report significant differences in the activities of glutathione-related enzymes (GSH-Px, GR, and GST) (Table 5). Furthermore, the total antioxidant capacity based on the ABTS assay resulted in a significant increase $(p<0.001)$ in the CSS6 and CSS11 compared to the CON and CSS16. Additionally, ABTS depicted a significant peak on the 30th experimental day ( $p$ $<0.001)$, leading to a significant interaction $(p<0.001)$ between the dietary treatment and the sampling time. In contrast, in the CSS16, the total antioxidant capacity measured by the FRAP assay was significantly higher $(p=0.008)$ compared to the CON and CSS6, while the overall antioxidant capacity measured by FRAP was suppressed on the 45th experimental day $(p=0.001)$. Interestingly, regarding oxidative stress indicators, MDA demonstrated a significant increase $(p<0.001)$ in the CSS11 compared to the CSS6 and CON, while PCs were significantly increased $(p<0.001)$ in CSS16 compared to the rest groups.

Table 5. Enzyme activities (Units/mL), total antioxidant capacity, and oxidative status biomarkers in blood plasma and milk of ewes fed diets (CON, CSS6, CSS11, CSS16) with different levels of Camelina seeds (6\%, 11\%, and $16 \%$ of concentrate) throughout the experimental period (15th, 30th, 45th, and 60th experimental days).

\begin{tabular}{|c|c|c|c|c|c|c|c|c|c|c|c|c|c|}
\hline & \multicolumn{5}{|c|}{ Dietary Treatment (D) } & \multicolumn{5}{|c|}{ Sampling Time (S) } & \multicolumn{3}{|c|}{ Effect $^{b}$} \\
\hline & $\mathrm{CON}$ & CSS6 & CSS11 & CSS16 & SEM $^{a}$ & 15 & 30 & 45 & 60 & SEM $^{a}$ & D & $\mathrm{S}$ & $\mathrm{D} \times \mathrm{S}$ \\
\hline \multicolumn{14}{|c|}{ Blood Plasma } \\
\hline SOD & $14.44^{\mathrm{a}}$ & $15.57^{\mathrm{ab}}$ & $15.98^{a b}$ & $16.91^{\mathrm{b}}$ & 0.426 & $14.36^{\mathrm{A}}$ & $14.91^{\mathrm{B}}$ & $17.05^{\mathrm{C}}$ & $16.57^{\mathrm{C}}$ & 0.400 & 0.014 & $<0.001$ & 0.109 \\
\hline CAT & $19.37^{\mathrm{a}}$ & $22.17^{\mathrm{a}}$ & $22.93^{b}$ & $22.18^{b}$ & 0.522 & $21.46^{\mathrm{A}}$ & $22.94^{\text {B }}$ & $21.17^{\mathrm{A}}$ & $21.10^{\mathrm{A}}$ & 0.556 & 0.006 & 0.052 & 0.536 \\
\hline GSH-Px & 0.24 & 0.26 & 0.28 & 0.27 & 0.009 & $0.33^{\mathrm{D}}$ & $0.27^{\mathrm{C}}$ & $0.24^{\text {в }}$ & $0.22 \mathrm{~A}$ & 0.007 & 0.112 & $<0.001$ & 0.189 \\
\hline GR & 0.05 & 0.05 & 0.05 & 0.06 & 0.001 & $0.049 \mathrm{~A}$ & $0.054^{\text {B }}$ & $0.051 \mathrm{~A}$ & $0.054^{\text {B }}$ & 0.001 & 0.102 & 0.011 & $<0.001$ \\
\hline GSTs & $0.15^{\mathrm{t}}$ & $0.17^{\mathrm{a}}$ & $0.17^{\mathrm{a}}$ & $0.19^{t}$ & 0.009 & $0.14^{\mathrm{A}}$ & $0.19^{\mathrm{B}}$ & $0.19^{\mathrm{B}}$ & $0.16^{\mathrm{A}}$ & 0.009 & 0.137 & $<0.001$ & 0.025 \\
\hline ABTS & $30.10^{a}$ & $32.81^{\mathrm{b}}$ & $33.52^{b}$ & $31.01^{\mathrm{a}}$ & 0.554 & $31.04^{\text {В }}$ & $34.70^{\mathrm{C}}$ & $31.79^{\text {В }}$ & 29.91 A & 0.518 & $<0.001$ & $<0.001$ & $<0.001$ \\
\hline FRAP & $0.93^{\mathrm{a}}$ & $0.91^{\mathrm{a}}$ & $0.97^{\mathrm{ab}}$ & $1.04^{\mathrm{b}}$ & 0.028 & $1.00^{\mathrm{B}}$ & $0.99^{\mathrm{B}}$ & $0.88^{\mathrm{A}}$ & $0.98^{\mathrm{B}}$ & 0.028 & 0.008 & 0.001 & $<0.001$ \\
\hline MDA & $0.63^{\mathrm{ac}}$ & $0.61^{\mathrm{a}}$ & $0.74^{\mathrm{b}}$ & $0.70^{\mathrm{cb}}$ & 0.021 & 0.66 & 0.66 & 0.69 & 0.66 & 0.022 & $<0.001$ & 0.516 & $<0.001$ \\
\hline PC & $2.45^{\mathrm{a}}$ & $2.24^{\mathrm{a}}$ & $2.47^{\mathrm{a}}$ & $3.08^{b}$ & 0.213 & $3.35^{C}$ & $2.71^{\mathrm{BC}}$ & $2.31 \mathrm{AB}$ & $1.87^{\mathrm{A}}$ & 0.195 & $<0.001$ & $<0.001$ & $<0.001$ \\
\hline \multicolumn{14}{|c|}{ Milk } \\
\hline SOD & $131.49^{a}$ & $142.76^{\mathrm{ab}}$ & $141.37^{\mathrm{ab}}$ & $149.63^{b}$ & 1.685 & $131.78^{\mathrm{A}}$ & $143.27^{\mathrm{BC}}$ & $140.11^{\mathrm{B}}$ & $150.09^{\mathrm{C}}$ & 3.245 & 0.019 & 0.006 & 0.109 \\
\hline CAT & $3.68^{\mathrm{a}}$ & $5.16^{\mathrm{b}}$ & $5.96^{\mathrm{b}}$ & $7.85^{c}$ & 0.359 & $5.70^{\mathrm{B}}$ & $7.02^{\mathrm{C}}$ & $4.45^{\mathrm{A}}$ & $5.49^{\mathrm{B}}$ & 0.391 & $<0.001$ & $<0.001$ & 0.007 \\
\hline GSH-Px & $0.28^{\mathrm{a}}$ & $0.32^{b}$ & $0.31^{\mathrm{b}}$ & $0.32^{b}$ & 0.007 & $0.31^{\mathrm{B}}$ & $0.33^{C}$ & $0.27 \mathrm{~A}$ & $0.32^{\mathrm{BC}}$ & 0.007 & $<0.001$ & $<0.001$ & $<0.001$ \\
\hline ABTS & $48.04^{\mathrm{ab}}$ & $50.32^{b}$ & $53.36^{c}$ & $54.46^{\mathrm{bc}}$ & 1.412 & $54.71^{\text {в }}$ & $45.99 \mathrm{~A}$ & $47.02 \mathrm{~A}$ & $58.46^{\mathrm{C}}$ & 1.221 & 0.001 & $<0.001$ & $<0.001$ \\
\hline FRAP & $3.00^{\mathrm{a}}$ & $4.77^{\mathrm{b}}$ & $5.21 \mathrm{bc}$ & $5.85^{c}$ & 0.302 & $4.33^{\mathrm{B}}$ & $3.56^{\mathrm{A}}$ & $3.66^{\mathrm{A}}$ & $7.27^{\mathrm{C}}$ & 0.261 & 0.008 & 0.001 & $<0.001$ \\
\hline MDA & $0.24^{\mathrm{ab}}$ & $0.25^{a b}$ & $0.26^{\mathrm{b}}$ & $0.21^{\mathrm{a}}$ & 0.244 & $0.21^{\mathrm{A}}$ & $0.25^{\text {в }}$ & $0.27^{\mathrm{BC}}$ & $0.22 \mathrm{AB}$ & 0.242 & 0.036 & 0.023 & 0.074 \\
\hline PC & $1.71^{\mathrm{b}}$ & $1.63^{b}$ & $1.60^{\mathrm{b}}$ & $1.28^{\mathrm{a}}$ & 0.086 & $1.20^{\mathrm{A}}$ & $1.77^{\mathrm{B}}$ & $1.68^{\text {B }}$ & $1.57^{\text {B }}$ & 0.080 & $<0.001$ & $<0.001$ & $<0.001$ \\
\hline
\end{tabular}

Means with different superscript letters $(a, b, c)$ between dietary groups and $(A, B, C, D)$ between sampling time points differ significantly. a SEM: Standard error of the means. ${ }^{b}$ Effect: The dietary treatment (D), time (S), and the interaction between dietary treatment $\times$ time (D $\times$ S) effects were analyzed by ANOVA using a general linear model (GLM) for repeated measures, and post-hoc analysis was performed with appropriate use of Tukey's multiple range test. FRAP is expressed as $\mu \mathrm{M}$ ascorbic acid equivalents, ABTS as $\%$ inhibition, MDA as $\mu \mathrm{M}$ $\mathrm{MDA}$, and $\mathrm{PC}$ as $\mathrm{nmol} / \mathrm{mL}$.

As for milk antioxidant enzyme activities, SOD activity was significantly increased $(p=0.019)$ in the CSS16. Similarly, SOD activity was significantly enhanced after the 15th experimental day $(p<0.001)$. Furthermore, CAT activity was significantly increased $(p<0.001)$ in the Camelina-fed ewes. More specifically, in the CSS16, CAT activity was significantly higher compared to CSS6 and CSS11, while even two-fold increase compared to the CON. Similarly, GSH-Px activity was also significantly higher $(p<0.001)$ in the Camelina-fed ewes. Interestingly, for both CAT and GSH-Px activity, the significant increase occurred in the 15th, 30th, and 60th compared to the 45th $(p<0.001)$ experimental day, leading to a significant interaction between the dietary treatment with the sampling time ( $p=0.007$, and $p<0.001$ for CAT and GSH-Px, respectively). Concerning milk's oxidative 
stress biomarkers, the highest MDA level was recorded in the CSS11, while the lowest was in the CSS16. Consequently, MDA was found to be significantly higher $(p=0.036)$ only for the CSS11 compared to the CSS16, with the same trend being reported in the 30th and 45 th experimental days compared to the 15 th $(p=0.023)$. Moreover, PCs were found to be significantly lower $(p<0.001)$ in the CSS16 compared to the rest groups. The PCs levels were significantly lower on the 15th experimental day compared to the rest $(p<0.001)$. Finally, we reported a statistically significant enhancement $(p=0.001)$ in the antioxidant capacity measured by ABTS assay in the CSS11 and CSS16. Moreover, FRAP values were significantly elevated in the Camelina-fed ewes and compared to the CON $(p=0.008)$. This increase in FRAP was linear amongst the four experimental groups and specifically in the CSS16 was significantly higher compared to the CSS6. For both ABTS and FRAP, the significant increase was reported in the first and the last sampling time compared to the 30th and 45th ( $p<0.001$, and $p=0.001$ for ABTS and FRAP, respectively), which led to the significant interaction between the dietary treatments and the sampling time $(p<0.001)$ (Table 5).

\section{Discussion}

Without a doubt, supplementing Camelina seeds and their by-products in favor of soybean meal in animal diets can be considered a sustainable strategy in developing highnutritional dairy products, simultaneously contributing against the environmental burden, and preserving biodiversity. However, caution should arise concerning the oxidative stability of both animal organisms and derived products. Since a diet supplemented with Camelina seeds probably exceeds the acceptable limits of dietary fat being offered to animals, and owing to a high PUFA content, the oxidative stability should also be determined to assess the optimum level of inclusion that would develop a high-quality product with desirable shelf-life longevity that respects the organism's oxidative status. Furthermore, our study covered a 60-day experimental period, that ensured for each ewe the individual feeding had no adverse effect on their performance. Hence, we believe that our results could be a reference point for further assumptions and investigation to be conducted regarding the constant consumption of Camelina seeds that would partially substitute soybean meal in ewes' diets and the possible impact of the antinutritional compounds that are presented.

\subsection{The Inclusion of Camelina Seeds Had a Minor Impact on Milk Performance}

Up until now, the inclusion of Camelina seeds in ruminant diets had a controversial impact on ruminants' milk performance. In agreement with our findings, Hurtaud and Peyraud [25] and Mierlita et al. [6], did not report any significant difference concerning milk yield, when Camelina seeds and meal were included in both cows' and ewes' diets respectively. In contrast, Mierlita et al. [8] reported increased milk yield in ewes fed with pasture combined with a concentrate that included Camelina seeds $(100 \mathrm{~g} / \mathrm{kg})$. Bayat et al. [26] reported that supplementing Camelina oil in dairy cows (60 g/ $\mathrm{kg} \mathrm{DM})$, reduced milk yield and ECM yield. In concurrence with our study, Szumacher-Strabel et al. [27], reported significantly lower milk fat concentration after supplementing ewes' diets with Camelina sativa cake. Contrary to our findings, offering Camelina seeds in ewes increased milk fat when animals were under grazing management $(80 \mathrm{~g} / \mathrm{d})$ and in a study that was under a pasture-based dairy system $(100 \mathrm{~g} / \mathrm{d})[6,8]$. Bayat et al. [26] reported that the dietary supplementation with Camelina oil, reduced milk fat, milk protein, and lactose in dairy cows. In our study, the decreased milk fat content that was reported in the group with the highest level of supplementation, leads us to the conclusion that supplementing Camelina seeds up to $16 \%$, may contribute to the so-called milk fat depression (MFD). Indeed, supplementing oilseeds in dairy cows tends to reduce milk fat content, causing

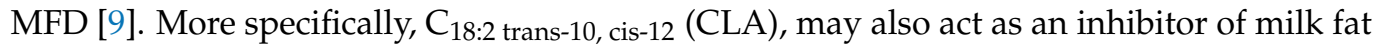
synthesis, and a high amount of milk total trans- FA concentration may also contribute to MFD [9]. However, more research is required referring to ewes and goats. What should 
also be noted is the fact that increased levels of PUFA lead to significant enhancement of ethanal synthesis during lactose-alcohol fermentation of sheep milk [28]. Furthermore, an increase in PUFA content could significantly affect the aroma profile of the kefir, by resulting in a loss of the animal odor in sheep milk kefir Cais-Sokolińska [28].

\subsection{Supplementing Camelina Seeds Improves Ewes' Milk Fatty Acid Profile}

Camelina seed oil is richer in PUFA (73\%) compared with other oilseeds like flaxseed, sunflower, soybean, and rapeseed [25]. The oil contains at average mainly ALA ( 37\%), $\mathrm{C}_{18: 2 \mathrm{n}-6}(15.2 \%), \mathrm{C}_{18: 1 \text { cis-9 }}(\sim 15 \%), \mathrm{C}_{20: 1 \mathrm{n}-9}(15.5 \%)$, and $\mathrm{C}_{22: 1 \mathrm{n}-9}(\sim 3 \%)$ [29]. Concerning milk FA profile, in compliance with our results, previous studies investigated the inclusion of Camelina seeds, oil, meal, cake, and expeller in ruminant diets and found decreased SFA content $[6-8,25,26]$. It has been reported that including oilseeds rich in $\mathrm{C}_{18}$ UFA in ruminant diets, reduces the proportion of SCFA and MCFA in milk [30]. Although oilseeds are responsible for dose-dependent decreases in the concentration of $C_{10: 0}$ to $C_{16: 0} F A$ [31], they also result in an increased proportion of the $C_{18: 0}, C_{18: 1 \text { cis-9, }}$ and total $C_{18: 1 \text { trans, which }}$ is also confirmed in the current study. In particular, the reduction of the SFA in favor of $\mathrm{C}_{18: 0}$ can be justified by the fact that LCFAs are transferred mostly from blood, and they compete for the de novo lipogenesis of SCFA and MCFA in the mammary gland [32]. Still, the decreased proportions of $\mathrm{C}_{14: 0}, \mathrm{C}_{15: 0}, \mathrm{C}_{16: 0}$, and $\mathrm{C}_{17: 0}$ that were found in treated ewes' milk samples, are also verified in their blood plasma.

Increases in $C_{18: 1 ~ c i s-9}$ and total $C_{18: 1 \text { trans }}$ were also observed through the supplementation of oilseeds in ruminant diets [31]. Indeed, supplementing ruminant diets with oilseeds rich in PUFA and especially in ALA may increase the $C_{18: 1}$ trans $-F A$, due to the lipolysis and biohydrogenation of $C_{18}$ PUFA in the rumen [33]. Additionally, the reported increase in the proportion of $\mathrm{C}_{18: 1 \text { trans-11 }}$ that we observed, was also reported in ewes fed with Camelina seeds and meal [6-9]. In the same direction, in cows, Camelina seeds and meal, increased total MUFA content and the proportion of total $C_{18: 1}$ trans $[25,26]$. Still, the reported increase in the proportion of $\mathrm{C}_{18: 1 \text { trans-11 }}$ in ovine milk occurs probably due to the action of the long-chain $\omega 3$ PUFA, which inhibits the final step of biohydrogenation [34].

Feeding whole oilseeds rather than the extracted oil is a more efficient way to enrich milk fat PUFA concentrations, due to the seed coat protecting the lipids from lipolysis and biohydrogenation in the rumen [33]. The ability to enrich ruminant milk with ALA was reported to be narrowed even when oilseeds rich in ALA are offered in ruminants [31]. However, in our study, ALA was linearly and significantly increased in treated with Camelina seeds ovine milk, indicating an efficient transfer in the three different studied levels of inclusion. Still, the apparent transfer efficiency of ALA was linearly decreased amongst the treated groups. This small increase in its proportion in milk is attributed to the biohydrogenation of PUFA in the rumen suggesting that most of the dietary ALA are exposed to extensive biohydrogenation in the rumen by the ruminal bacteria [35].

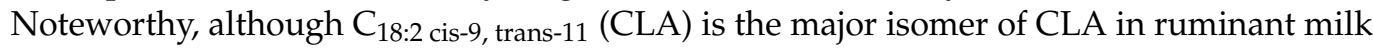
and is an intermediate of the biohydrogenation of linoleic acid, its majority in milk fat is

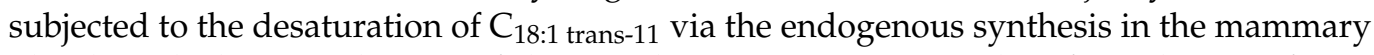
gland, with the contribution of the $\Delta-9$ desaturase enzyme. Therefore, the significant linear increase in the proportion of $\mathrm{C}_{18: 2}$ cis-9, trans-11 (CLA) in ewes' milk, is linked with the

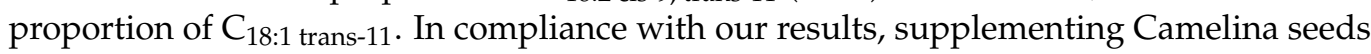
increased the proportion of ALA and CLA in ovine milk [6-9]. In addition, in ewes that were under grazing management and were offered Camelina seeds $(80 \mathrm{~g} / \mathrm{d})$ the proportions

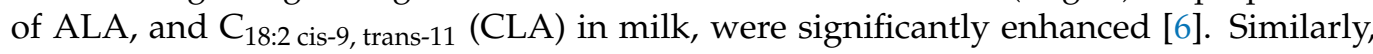
ewes that were offered grass or maize silage with $70 \mathrm{~g} / \mathrm{kg}$ DM Camelina seeds resulted in a significant increase in ALA and CLA proportions in milk [7]. Furthermore, combining pasture and concentrates that included Camelina seeds (100 g/ $\mathrm{kg}$ in the concentrate),

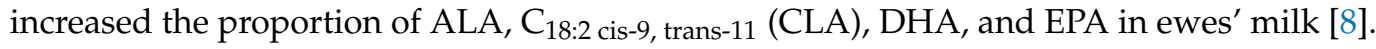
In contrast, Hurtaud and Peyraud [25] reported that including Camelina in dairy cow diets did not significantly alter the proportion of ALA, while it increased that of CLA. 
Furthermore, supplementing $60 \mathrm{~g}$ of Camelina oil/ $\mathrm{kg}$ of DM in dairy cows' increased C18:2, ALA, CLA, total $C_{20: 0}$ and $C_{22: 0}$, PUFA, and total trans- FA proportions [26].

Noteworthy, w3 PUFA, cannot be effectively synthesized by ruminant's tissues. Their inclusion in human diets was linked with reducing the risk of heart attacks, coronary heart diseases, skin diseases, and arthritis. They can also reduce systemic inflammation and improve insulin resistance [36]. Besides, it is worth mentioning that $C_{18: 2 \text { cis-9, trans-11 }}$ (CLA), which is also known as rumenic acid, gained major attention for its anticarcinogenic and antiatherogenic ability [37]. Therefore, the reported increased proportions of the aforementioned FAs in the treated with Camelina seed groups is considered a remarkable highlight towards developing a high-nutrition product from a consumer perspective.

In our study, a favorable outcome is also the fact that AI and $\omega 6 / \omega 3$, were linearly decreased in the treatment groups and compared to the CON since higher AI and $\omega 6 / \omega 3$ ratio are considered harmful for health [38]. Still, the reported significant alterations in the TI and the HPI were in favor of improving milk quality from a human health perspective.

In this study, the correlation amongst principal FA further confirms the aforementioned hypothesis regarding the competition of ALA and SFA. More specifically, the proportion of milk ALA was negatively correlated with $\mathrm{C}_{16: 0}$, SFA, and MCFA. In contrast, the biohydrogenation of ALA to $C_{18: 1}$ trans isomers was also confirmed by its positive correlation with $C_{18: 1 \text { trans, }} C_{18: 1 \text { cis-9 }}$ and CLA. Notably, the correlation of ALA with $C_{18: 1}$ cis-9 and CLA does not indicate a direct relationship but unveils their formation through the stearic acid desaturation within the mammary gland.

\subsection{Antioxidant Mechanisms Were Triggered to Preserve a Stable Oxidative Status in Ewes' Blood Plasma While Milk Oxidative Status Was Promoted}

The so-called oxidative stress occurs when there is an imbalance between the free radicals production and the antioxidant mechanisms. Therefore, since PUFA constitutes more than half of the total FA presented in Camelina, a common belief would suggest that this oil would demonstrate low oxidative stability [39]. Although high inclusion levels of $\omega 3$ long-chain PUFA in diets could induce oxidative imbalances as previously stated, prudent doses can activate antioxidant mechanisms in several cells [11] and thus restrain oxidative stress [40]. Camelina oil exhibits strong oxidative stability compared to flax oil, which is also rich in unsaturated fatty acids, but it is less stable compared with rapeseed, sesame, and sunflower oil [39]. As previously stated, Camelina oil is a remarkable source of $\gamma$-tocopherol [29]. Besides, it is a rich source of total phenolic compounds and flavonoids [41].

To the best of our knowledge, there is a lack of studies that investigate the optimum inclusion level of Camelina seeds that do not jeopardize ewes' oxidative status and consequently their performance. In our study, the highest inclusion level $(16 \%)$ increased the activity of SOD, which is the first line of defense against ROS [42]. This may be a precursor of a response to tolerate oxidation stress. More specifically, the increase in SOD activity may be a response towards neutralizing an increased concentration of superoxide anion $\left(\mathrm{O}_{2}{ }^{\bullet-}\right)$. Supplementing $\omega 3$ PUFA in human diets is in favor of formatting $\mathrm{O}_{2}{ }^{\bullet-}$ [43], through the mitochondria respiratory. In agreement, palmitic acid in rat diets presents similar activity [44]. Besides, NADPH oxidase also provokes the concentration of $\mathrm{O}_{2}{ }^{\bullet-}$ [45]. Increased SOD activity was also reported in goats' blood plasma that was fed with high PUFA content [46]. Furthermore, supplementing whole sesame seeds in goats' diets [47], also increased the SOD activity. The increased SOD activity in blood plasma and the increased levels of $\mathrm{O}_{2}{ }^{\bullet-}$, catalyze efficiently the conversion of the latter to hydrogen peroxide $\left(\mathrm{H}_{2} \mathrm{O}_{2}\right)$, a lesser unstable radical, and consequently results in an increased level of $\mathrm{H}_{2} \mathrm{O}_{2}$ and its by-products.

Following the above, the $\mathrm{H}_{2} \mathrm{O}_{2}$ is detoxified by CAT and/or by GSH-Px. More specifically, CAT is responsible for the removal of the peroxides and their conversion into $\mathrm{O}_{2}$ [48]. In particular, the activity of CAT was found elevated in CSS11 and CSS16 compared to the CON, probably because of the increased substrate levels. However, the activity of CAT alone probably was unable to detoxify the $\mathrm{H}_{2} \mathrm{O}_{2}$ successfully, since GSH-Px activity 
did not differ significantly amongst the experimental groups. Increased CAT activity was also reported in goats fed with whole sesame seeds [47].

Owing to $\mathrm{H}_{2} \mathrm{O}_{2}$ action, higher production of the hydroxyl radical $\left(\mathrm{OH}^{-}\right)$may result, due to the Fenton reaction. This is supported in our case, through the higher reported concentration of MDA in the CSS11 and CSS16 blood. However, the lowest level of inclusion of Camelina seeds (6\%), resulted in the lowest observed MDA level, compared to the CSS11 and CSS16. This may be related to low-grade oxidative stress that triggers the antioxidant mechanisms to neutralize lipid peroxidation in CSS6. Thus, the increased levels of PUFA in the two highest levels in ewes' diets, may contribute to this upsurge in the MDA. Notably, MDA was determined as the most studied product of lipid peroxidation [23]. Nevertheless, the reported levels of MDA were within range compared to studies that were conducted with dairy ewes [49,50]. Likewise, PC was considered a biomarker of oxidative damage of proteins [51]. The reported level of PC in the experimental groups followed the same trend with those of MDA, which further supports the assumption of an oxidative response in the highest studied level of inclusion of Camelina seeds in ewes' diets. As a matter of fact, a high dose of PUFA in goats' diets, also resulted in increased MDA and PC levels [46]. Interestingly, the increased level of PC in the CSS16 group may be associated with the proteins' oxidative damage by the oxygen-free radicals.

Contrary to the observations regarding the effect of the highest levels of inclusion of Camelina seeds in ewes' oxidative status (blood), milk's oxidative stability was strongly supported and not imperiled. Despite the significant linear increase that was previously reported in PUFA in the treated with Camelina seeds groups and compared to the CON, we achieved strong oxidative stability. In agreement with our results, Mierlita et al. [7] also reported that ewes being under a grass-silage-based diet and supplemented with Camelina seeds enhanced milk oxidative stability, which was measured with the Trolox equivalent antioxidant capacity. Nevertheless, we thoroughly approached milks' oxidative stability mostly by determining not only the antioxidant capacity but also the activity of key targeted antioxidant enzymes that are involved in the antioxidant mechanisms, and oxidative stress biomarkers.

First and foremost, supplementing Camelina seeds in the three studied levels of inclusion boosted the key targeted antioxidant enzyme activities, and antioxidant capacity. Noteworthy, the oxidative stress biomarkers were not affected. This combined reported elevation in the activity of the studied antioxidant enzymes in ewes' milk, alongside the significant increase in milk antioxidant capacity may result in a more stable product with better organoleptic characteristics and extensive shelf-life [21]. In a previous study, supplementing whole sesame seeds also boosted the antioxidant capacity that was measured with ABTS and FRAP assays in goats' milk [47]. Moreover, supplementing both ewes and goats with PUFA also resulted in increased levels of CAT and FRAP [52]. In contrast, an infusion with high linolenic fatty acid in dairy cows, despite resulting in enhanced content of $\omega 3$ PUFA in milk, also negatively affected its oxidative stability [53], while supplementing ALA in vitro, was linked with increased free radical production in prostate cells compared with the supplementation with linoleic acid [54]. Finally, the fact that the oxidative stress biomarkers were not significantly altered in our study, further supports the assumption that milk' oxidative stability was not jeopardized and there is a firm potential of developing a dairy product of high nutritional value to meet the consumer demands.

\section{Conclusions}

Camelina seeds demonstrate a noteworthy protein substitution for soybean meal in ewes' diets. However, more research is needed to investigate its constant consumption, owing to the presence of antinutritive factors. Overall, supplementing ewes' diets with the three inclusion levels $(6,11$, and $16 \%)$, improved milk fatty acid profile from a human health point (increase PUFA and decrease SFA) as it was also reported in the literature. Nevertheless, the $6 \%$ inclusion level of Camelina seeds in the concentrates beneficially affected ewes' oxidative status and milk oxidative stability. Therefore, enriching ewes' diets 
with Camelina seeds (6\%) portray an efficient protein substitution for soybean meal but also a decisive way to meet the global market trends, which are expressed by the increasing consumer demands of high nutritional and functional animal dairy products that promote human health.

Supplementary Materials: The following are available online at https:/ /www.mdpi.com/article/10 .3390/foods10092076/s1. Supplementary file.

Author Contributions: Conceptualization, E.T.; methodology, C.C. and C.M.; software, C.C. and K.S.; validation, G.S., V.D. and B.K.; formal analysis, K.S., C.C. and A.M.; investigation, E.T.; resources, E.T.; data curation, C.C.; writing-original draft preparation, C.C.; writing-review and editing, A.M., E.T. and B.K.; visualization, C.C. and A.M.; supervision, E.T.; project administration, E.T.; funding acquisition, E.T. All authors have read and agreed to the published version of the manuscript.

Funding: This research received no external funding.

Institutional Review Board Statement: The study was conducted according to the guidelines of the European Union Directive on the protection of animals used for scientific purposes (EU 63/2010; Council of the European Union 2010), while taking into account an extended experimental design report, the Bioethical Committee of Faculty of Animal Science (currently known as: Agricultural University of Athens Ethical Committee in Research; FEK 38/A/2-3-2018, eide.aua) approved the experimental protocol under the No. 000007/22-01-2017.

Informed Consent Statement: Not applicable.

Data Availability Statement: All data are contained within the article and supplementary file.

Acknowledgments: We sincerely thank the anonymous reviewers for their valuable comments and suggestions.

Conflicts of Interest: The authors declare no conflict of interest.

\section{References}

1. Livingstone, K.M.; Lovegrove, J.A.; Givens, D.I. The impact of substituting SFA in dairy products with MUFA or PUFA on CVD risk: Evidence from human intervention studies. Nutr. Res. Rev. 2012, 25, 193-206. [CrossRef]

2. Antonio Gagliostro, G.; Elisabet Antonacci, L.; Daiana Pérez, C.; Rossetti, L.; Carabajal, A. Improving Concentration of Healthy Fatty Acids in Milk, Cheese and Yogurt by Adding a Blend of Soybean and Fish Oils to the Ration of Confined Dairy Cows. Open J. Anim. Sci. 2020, 10, 182-202. [CrossRef]

3. Berhow, M.; Vaughn, S.; Moser, B.; Belenli, D.; Polat, U. Evaluating the Phytochemical Potential of Camelina: An Emerging New Crop of Old World Origin. In Phytochemicals—Biosynthesis, Function and Application. Recent Advances in Phytochemistry; Jetter, R., Ed.; Springer: New York, NY, USA, 2014; Volume 44, pp. 129-148. ISBN 978-3-319-04045-5.

4. Pendrill, F.; Persson, U.M.; Godar, J.; Kastner, T.; Moran, D.; Schmidt, S.; Wood, R. Agricultural and forestry trade drives large share of tropical deforestation emissions. Glob. Environ. Chang. 2019, 56, 1-10. [CrossRef]

5. Singh, S.K.; Rajpurohit, B.; Singha, P. Camelina (Camelina sativa) Seed. In Oilseeds: Health Attributes and Food Applications; Tanwar, B., Goyal, A., Eds.; Springer: Singapore, 2021; pp. 455-471. ISBN 978-981-15-4194-0. [CrossRef]

6. Mierlita, D.; Daraban, S.; Lup, F.; Chereji, A. The effect of grazing management and camelina seed supplementation in the diet on milk performance and milk fatty acid composition of dairy ewes. J. Food Agric. Environ. 2011, 9, 368-373.

7. Mierlita, D.; Vicas, S. Dietary effect of silage type and combination with camelina seed on milk fatty acid profile and antioxidant capacity of sheep milk. S. Afr. J. Anim. Sci. 2015, 45, 1-11. [CrossRef]

8. Mierlita, D.; Pop, I.M.; Lup, F.; Simeanu, D.; Vicas, S.I.; Simeanu, C. The fatty acids composition and health lipid indices in the sheep raw milk under a pasture-based dairy system. Rev. Chim. 2018, 69, 160-165. [CrossRef]

9. Shingfield, K.J.; Griinari, J.M. Role of biohydrogenation intermediates in milk fat depression. Eur. J. Lipid Sci. Technol. 2007, 109, 799-816. [CrossRef]

10. Tao, L. Oxidation of Polyunsaturated Fatty Acids and its Impact on Food Quality and Human Health Article History. Adv. Food Technol. Nutr. Sci. 2015, 1, 135-142. [CrossRef]

11. Giordano, E.; Visioli, F. Long-chain omega 3 fatty acids: Molecular bases of potential antioxidant actions. Prostaglandins Leukot. Essent. Fat. Acids 2014, 90, 1-4. [CrossRef] [PubMed]

12. Abramovič, H.; Butinar, B.; Nikolič, V. Changes occurring in phenolic content, tocopherol composition and oxidative stability of Camelina sativa oil during storage. Food Chem. 2007, 104, 903-909. [CrossRef]

13. Devaraj, S.; Leonard, S.; Traber, M.G.; Jialal, I. Gamma-tocopherol supplementation alone and in combination with alphatocopherol alters biomarkers of oxidative stress and inflammation in subjects with metabolic syndrome. Free Radic. Biol. Med. 2008, 44, 1203-1208. [CrossRef] 
14. AOAC. Official Methods of Analysis, 14th ed.; Williams, S., Ed.; Association of Official Analytical Chemists Inc.: Arlington, VA, USA, 1984

15. Soxhlet, F. Die gewichtsanalytische Bestimmung des Milchfettes. Dinglers Polytech. J. 1879, 232, 461-465.

16. Van Soest, P.J.; Robertson, J.B.; Lewis, B.A. Methods for Dietary Fiber, Neutral Detergent Fiber, and Nonstarch Polysaccharides in Relation to Animal Nutrition. J. Dairy Sci. 1991, 74, 3583-3597. [CrossRef]

17. O'Fallon, J.V.; Busboom, J.R.; Nelson, M.L.; Gaskins, C.T. A direct method for fatty acid methyl ester synthesis: Application to wet meat tissues, oils, and feedstuffs. J. Anim. Sci. 2007, 85, 1511-1521. [CrossRef]

18. Bondia-Pons, I.; Castellote, A.I.; López-Sabater, M.C. Comparison of conventional and fast gas chromatography in human plasma fatty acid determination. J. Chromatogr. Analyt. Technol. Biomed. Life Sci. 2004, 809, 339-344. [CrossRef]

19. Tsiplakou, E.; Mountzouris, K.C.; Zervas, G. Concentration of conjugated linoleic acid in grazing sheep and goat milk fat. Livest. Sci. 2006, 103, 74-84. [CrossRef]

20. Mavrommatis, A.; Tsiplakou, E. The impact of the dietary supplementation level with Schizochytrium sp. on milk chemical composition and fatty acid profile, of both blood plasma and milk of goats. Small Rumin. Res. 2020, 193, 106252. [CrossRef]

21. Tsiplakou, E.; Abdullah, M.A.M.; Mavrommatis, A.; Chatzikonstantinou, M.; Skliros, D.; Sotirakoglou, K.; Flemetakis, E.; Labrou, N.E.; Zervas, G. The effect of dietary Chlorella vulgaris inclusion on goat's milk chemical composition, fatty acids profile and enzymes activities related to oxidation. J. Anim. Physiol. Anim. Nutr. 2018, 102, 142-151. [CrossRef] [PubMed]

22. Tsiplakou, E.; Mitsiopoulou, C.; Mavrommatis, A.; Karaiskou, C.; Chronopoulou, E.G.; Mavridis, G.; Sotirakoglou, K.; Labrou, N.E.; Zervas, G. Effect of under- and overfeeding on sheep and goat milk and plasma enzymes activities related to oxidation. J. Anim. Physiol. Anim. Nutr. 2018, 102, e288-e298. [CrossRef]

23. Nielsen, F.; Mikkelsen, B.B.; Nielsen, J.B.; Andersen, H.R.; Grandjean, P. Plasma malondialdehyde as biomarker for oxidative stress: Reference interval and effects of life-style factors. Clin. Chem. 1997, 43, 1209-1214. [CrossRef] [PubMed]

24. Patsoukis, N.; Zervoudakis, G.; Panagopoulos, N.T.; Georgiou, C.D.; Angelatou, F.; Matsokis, N.A. Thiol redox state (TRS) and oxidative stress in the mouse hippocampus after pentylenetetrazol-induced epileptic seizure. Neurosci. Lett. 2004, 357, 83-86. [CrossRef]

25. Hurtaud, C.; Peyraud, J.L. Effects of feeding camelina (seeds or meal) on milk fatty acid composition and butter spreadability. J. Dairy Sci. 2007, 90, 5134-5145. [CrossRef]

26. Bayat, A.R.; Kairenius, P.; Stefański, T.; Leskinen, H.; Comtet-Marre, S.; Forano, E.; Chaucheyras-Durand, F.; Shingfield, K.J. Effect of camelina oil or live yeasts (Saccharomyces cerevisiae) on ruminal methane production, Rumen fermentation, And milk fatty acid composition in lactating cows fed grass silage diets. J. Dairy Sci. 2015, 98, 3166-3181. [CrossRef] [PubMed]

27. Szumacher-Strabel, M.; Cieślak, A.; Zmora, P.; Pers-Kamczyc, E.; Bielińska, S.; Stanisz, M.; Wójtowski, J. Camelina sativa cake improved unsaturated fatty acids in ewe's milk. J. Sci. Food Agric. 2011, 91, 2031-2037. [CrossRef] [PubMed]

28. Cais-Sokolińska, D.; Wójtowski, J.; Pikul, J.; Danków, R.; Majcher, M.; Teichert, J.; Bagnicka, E. Formation of volatile compounds in kefir made of goat and sheep milk with high polyunsaturated fatty acid content. J. Dairy Sci. 2015, 98, 6692-6705. [CrossRef] [PubMed]

29. Zubr, J.; Matthaus, B. Effects of growth conditions on fatty acids and tocopherols in Camelina sativa oil. Ind. Crops Prod. 2002, 690, 155-162. [CrossRef]

30. Chilliard, Y.; Glasser, F.; Ferlay, A.; Bernard, L.; Rouel, J.; Doreau, M. Diet, rumen biohydrogenation and nutritional quality of cow and goat milk fat. Eur. J. Lipid Sci. Technol. 2007, 109, 828-855. [CrossRef]

31. Shingfield, K.J.; Bonnet, M.; Scollan, N.D. Recent developments in altering the fatty acid composition of ruminant-derived foods. Animal 2013, 7, 132-162. [CrossRef] [PubMed]

32. Chilliard, Y.; Ferlay, A. Dietary lipids and forages interactions on cow and goat milk fatty acid composition and sensory properties. Reprod. Nutr. Dev. 2004, 44, 467-492. [CrossRef] [PubMed]

33. Givens, D.I.; Kliem, K.E. Improving the nutritional quality of milk. In Woodhead Publishing Series in Food Science, Technology and Nutrition, Fuctional and Speciality Beverage Technology; Paquin, P., Ed.; Woodhead Publishing: Cambridge, UK, 2009 ; pp. 135-169. ISBN 9781845693428.

34. Dewanckele, L.; Jeyanathan, J.; Vlaeminck, B.; Fievez, V. Identifying and exploring biohydrogenating rumen bacteria with emphasis on pathways including trans-10 intermediates. BMC Microbiol. 2020, 20, 198. [CrossRef] [PubMed]

35. Gonthier, C.; Mustafa, A.F.; Ouellet, D.R.; Chouinard, P.Y.; Berthiaume, R.; Petit, H.V. Feeding micronized and extruded flaxseed to dairy cows: Effects on blood parameters and milk fatty acid composition. J. Dairy Sci. 2005, 88, 748-756. [CrossRef]

36. Shahidi, F.; Ambigaipalan, P. Omega-3 Polyunsaturated Fatty Acids and Their Health Benefits. Annu. Rev. Food Sci. Technol. 2018, 9, 345-381. [CrossRef]

37. Virsangbhai, C.K.; Goyal, A.; Tanwar, B.; Sihag, M.K. Potential Health Benefits of Conjugated Linoleic Acid: An Important Functional Dairy Ingredient. European J. Nutr. Food Saf. 2020, 11, 200-213. [CrossRef]

38. Bo, M.S.; Cheah, W.L.; Lwin, S.; Moe New, T.; Win, T.T.; Aung, M. Understanding the relationship between atherogenic index of plasma and cardiovascular disease risk factors among staff of an University in Malaysia. J. Nutr. Metab. 2018, 3, 1-6. [CrossRef] [PubMed]

39. Ní Eidhin, D.; Burke, J.; O’Beirne, D. Oxidative stability of $\omega 3$-rich Camelina oil and camelina oil-based spread compared with plant and fish oils and sunflower spread. J. Food Sci. 2003, 68, 345-353. [CrossRef] 
40. Zanatta, A.L.; Miranda, D.T.S.Z.; Dias, B.C.L.; Campos, R.M.; Massaro, M.C.; Michelotto, P.V.; West, A.L.; Miles, E.A.; Calder, P.C.; Nishiyama, A. Fish oil supplementation decreases oxidative stress but does not affect platelet-activating factor bioactivity in lungs of asthmatic rats. Lipids 2014, 49, 665-675. [CrossRef] [PubMed]

41. Russo, R.; Reggiani, R. Antioxidants in flour of the oilseed crop Camelina sativa (L.) Crantz. Int. J. Plant Biol. 2018, 9. [CrossRef]

42. Wang, Y.; Branicky, R.; Noë, A.; Hekimi, S. Superoxide dismutases: Dual roles in controlling ROS damage and regulating ROS signaling. J. Cell Biol. 2018, 217, 1915-1928. [CrossRef]

43. Duričić, I.; Kotur-Stevuljević, J.; Miljković, M.; Kerkez, M.; Dordević, V.; Durašić, L.; Šobajić, S. Effect of nutritionally relevant doses of long-chain N-3 pufa on lipid status, oxidative stress and inflammatory markers in an average middle-aged serbian population. J. Med. Biochem. 2015, 34, 304-313. [CrossRef]

44. Gao, Z.; Zhang, H.; Liu, J.; Lau, C.W.; Liu, P.; Chen, Z.Y.; Lee, H.K.; Tipoe, G.L.; Ho, H.M.; Yao, X.; et al. Cyclooxygenase-2dependent oxidative stress mediates palmitate-induced impairment of endothelium-dependent relaxations in mouse arteries. Biochem. Pharmacol. 2014, 91, 474-482. [CrossRef]

45. Katsuyama, M. NOX/NADPH oxidase, the superoxide-generating enzyme: Its transcriptional regulation and physiological roles. J. Pharmacol. Sci. 2010, 114, 134-146. [CrossRef]

46. Mavrommatis, A.; Sotirakoglou, K.; Kamilaris, C.; Tsiplakou, E. Effects of Inclusion of Schizochytrium spp. and Forage-toConcentrate Ratios on Goats' Milk Quality and Oxidative Status. Foods 2021, 10, 1322. [CrossRef]

47. Mitsiopoulou, C.; Sotirakoglou, K.; Labrou, N.E.; Tsiplakou, E. The effect of whole sesame seeds on milk chemical composition, fatty acid profile and antioxidant status in goats. Livest. Sci. 2021, 245, 104452. [CrossRef]

48. Yu, B.P. Cellular defenses against damage from reactive oxygen species. Physiol. Rev. 1994, 74, 139-162. [CrossRef] [PubMed]

49. Mavrommatis, A.; Mitsiopoulou, C.; Christodoulou, C.; Kariampa, P.; Simoni, M.; Righi, F.; Tsiplakou, E. Effects of supplementing rumen-protected methionine and lysine on milk performance and oxidative status of dairy ewes. Antioxidants 2021, 10, 654. [CrossRef]

50. Mavrommatis, A.; Mitsiopoulou, C.; Christodoulou, C.; Karabinas, D.; Nenov, V.; Zervas, G.; Tsiplakou, E. Dietary supplementation of a live yeast product on dairy sheep milk performance, oxidative and immune status in peripartum period. J. Fungi 2020, 6, 334. [CrossRef]

51. Weber, D.; Davies, M.J.; Grune, T. Determination of protein carbonyls in plasma, cell extracts, tissue homogenates, isolated proteins: Focus on sample preparation and derivatization conditions. Redox Biol. 2015, 5, 367-380. [CrossRef] [PubMed]

52. Tsiplakou, E.; Chatzikonstantinou, M.; Mitsiopoulou, C.; Karaiskou, C.; Mavrommatis, A.; Sotirakoglou, K.; Labrou, N.; Zervas, G. Effect of soya bean and fish oil inclusion in diets on milk and plasma enzymes from sheep and goat related to oxidation. $J$. Anim. Physiol. Anim. Nutr. 2017, 101, 733-742. [CrossRef] [PubMed]

53. Liu, Q.; Wang, J.; Bu, D.; Khas-Erdene; Liu, K.; Wei, H.; Zhou, L.; Beitz, D.C. Influence of linolenic acid content on the oxidation of milk fat. J. Agric. Food Chem. 2010, 58, 3741-3746. [CrossRef] [PubMed]

54. Meng, H.; Shen, Y.; Shen, J.; Zhou, F.; Shen, S.; Das, U.N. Effect of n-3 and n-6 unsaturated fatty acids on prostate cancer (PC-3) and prostate epithelial (RWPE-1) cells in vitro. Lipids Health Dis. 2013, 12, 1-14. [CrossRef] 